\title{
Research and Development Investment and Collaboration Framework for the Hydrogen Economy in South Korea
}

\author{
Doyeon Lee and Keunhwan Kim *
}

check for updates

Citation: Lee, D.; Kim, K. Research and Development Investment and Collaboration Framework for the Hydrogen Economy in South Korea. Sustainability 2021, 13, 10686. https:// doi.org/10.3390/su131910686

Academic Editor: Pablo

García Triviño

Received: 20 August 2021

Accepted: 24 September 2021

Published: 26 September 2021

Publisher's Note: MDPI stays neutral with regard to jurisdictional claims in published maps and institutional affiliations.

Copyright: (c) 2021 by the authors. Licensee MDPI, Basel, Switzerland. This article is an open access article distributed under the terms and conditions of the Creative Commons Attribution (CC BY) license (https:/ / creativecommons.org/licenses/by/ $4.0 /)$.
Center for R\&D Investment and Strategy Research, Division of Data Analysis, Korea Institute of Science and Technology Information (KISTI), 66, Hoegi-ro, Dongdaemun-gu, Seoul 02456, Korea; dylee@kisti.re.kr * Correspondence: khkim75@kisti.re.kr; Tel.: +82-2-3299-6072

\begin{abstract}
South Korea developed its hydrogen strategies to achieve carbon neutrality and dominate the hydrogen economy amidst, and with the impetus, of the coronavirus disease 2019 (COVID-19) pandemic. The government strives toward the goal via continuous investment in green hydrogen technologies, as well as strategic collaborations. To facilitate the transition into the hydrogen economy, this study presents a research and development (R\&D) investment and collaboration framework as a national strategy. The framework offers abundant information to elucidate the technology, R\&D spectrum, and regional dimensions of the strategy. Furthermore, the proposed framework was applied to the Korean hydrogen economy comprising 955 nationally funded projects worth USD 565.7 million. The statuses and trends of the government's investment in nationally funded research projects are illustrated with regard to the value chains of the hydrogen economies of 16 regions, as well as nine technology clusters relating to the hydrogen economy, thereby determining the research organizations that played crucial roles in each cluster of the 16 regions between 2015 and 2020 . The results indicate that the research organizations in Daejeon acquired the highest government R\&D funding in many hydrogen-economy-related research fields, and that an R\&D spectrum-based research/strategic collaboration is required to accomplish specialized complexes in the regions.
\end{abstract}

Keywords: Korean hydrogen economy; R\&D investment; collaboration; nationally funded project data; framework

\section{Introduction}

The "hydrogen economy", which is defined as a society where hydrogen (named by Antoine-Laurent de Lavoisier in 1783 [1]) is employed as the energy carrier in its energy system [2], emerged as a term in the early 1970s, following the oil crisis (1973-1974), as a strategy for eradicating the energy dependence of the West on the Middle East $[3,4]$. Since passing three international treaties, namely, the United Nations Framework Convention on Climate Change (UNFCCC, 1992), the Kyoto Protocol (1997), and the Paris Agreement (2015), developing and developed nations, including the US, Japan, as well as the EU have been competing to dominate the hydrogen economy, with the impetus of the coronavirus disease 2019 (COVID-19) pandemic [5-7]. South Korea (hereafter called Korea) ratified the agreement to join the global hydrogen competition on 3 November 2016 [8].

Governments across the globe have developed their hydrogen strategies as the centerpieces of their grand master plans to achieve carbon neutrality by reducing the emission of greenhouse gases (GHGs) [2,9]. In July 2020, the European Commission also adopted the "EU Hydrogen Strategy" as part of the European Green Deal, with strategic objectives, such as the installation of $\geq 40 \mathrm{GW}$ renewable hydrogen electrolyzers, as well as the production of up to $10 \times 10^{6}$ metric tons of renewable hydrogen each year until 2030 [10,11]. The Hydrogen Program Plan of the US Department of Energy, which was based on the National Hydrogen Energy Technology Roadmap (2002), was unveiled in November 2020 with key application-specific targets, such as achieving a hydrogen production of USD $2 / \mathrm{kg}$ and delivering and dispensing for the transportation applications by USD $2 / \mathrm{kg}$. Moreover, the 
"Road Map to a US Hydrogen Economy", which was released in March 2020 by the Fuel Cell and Hydrogen Energy Association (FCHEA), a Washington-based trade association, to achieve the hydrogen economy mission of the US, targets a hydrogen demand of $>1.7 \times 10^{6}$ metric tons across different applications (with 1.2 million fuel cell vehicles (FCEVs) sold, 300,000 material-handling FCEVs in the field, and 4300 fueling stations across the nation) by the end of 2030 [12]. In 2017, the Government of Japan designed its "Basic Hydrogen Strategy", which aims to expand the fuel supply to $3 \times 10^{5}$ metric tons/annum and supply $8 \times 10^{5}$ FCEVs, 1200 hydrogen buses, and 900 hydrogen fuel stations by 2030. Further, with regard to the annual volume targets, even the ambitious 10 million metric tons/annum can be employed to envisage the 2050 target [13]. Further, the Korean government announced its "Hydrogen Economy Roadmap" in January 2019 to achieve carbon neutrality, thereby improving hydrogen-related technologies and industrial structures $[9,14,15]$.

Although numerous studies have been devoted to emphasizing the resolve of the Korean government to reduce GHG emissions via several national hydrogen strategies that are based on effective collaborations with different stakeholders, such as private companies, academia, research institutes, and agencies, as well as ongoing public investments in green hydrogen technologies owing to concerns that are interlinked to climate change, air pollution, energy security, and global competitiveness in key industries [7,9], further studies are still required to develop a systematic framework for collaboration and investment for the hydrogen economy of Korea. To bridge this gap, a systematic collaboration and investment framework is proposed here. The framework supports the organization of a committee comprising stakeholders, and the implementation of the national hydrogen strategy, by presenting valuable and detailed information on public investments, as well as relevant implementation actors who can become the collaborative partners and/or members of the committee on a particular technology sector. Moreover, the proposed framework was applied to the value chain of the hydrogen economy to elucidate the implications of the strategy.

\subsection{Background and Literature Review}

\subsubsection{National Strategies of the Korean Hydrogen Economy}

With the increasing global demand for renewable energy sources to deal with climate change, Korea is aiming at becoming a global leader in pioneering a hydrogen-based economy $[7,9,14]$. The Korean government has emphasized its commitment to achieving net-zero carbon emissions by 2050 by announcing the "Hydrogen Economy Roadmap" (January 2019), establishing the "Hydrogen Economy Promotion and Safety Management Act" (Hydrogen Act) (February 2020 and enforced 5 February 2021), and establishing the "Green New Deal" (July 2020) [7,16]. These efforts have accelerated the production and utilization of hydrogen vehicles, the establishment of an ecosystem for producing and distributing hydrogen and other related technologies, and the production of fuel cells (FCs) [9]. Recently, the plans for private investment in the hydrogen economy, along with government support, were approved at the third meeting of the Korean Hydrogen Economy Council.

Although Korea has invested in photovoltaics and wind energy, its onshore wind and solar potentials are very limited [9]. Moreover, the Korean hydrogen industry is wellestablished and exhibits decades of experience in industrial energy employing hydrogen as a feedstock [9]. Hydrogen can be produced via several processes, such as steam-methane reforming (SMR), coal gasification, renewable liquid reforming employing ethanol, and electrolysis. An electrolyzer is a device that employs electricity to split water into hydrogen and oxygen. When electricity that is produced from renewable energy sources is employed in this process, the produced hydrogen becomes a renewable energy carrier, complementary to the applied electricity $[9,17]$. The hydrogen energy technologies that are based on multienergy systems that correspond to renewable energy, including solar, water, wind, and biomass energies, can improve the energy utilization rate and reduce the cost of hydrogen production and, therefore, represent the future of hydrogen energy [18]. Thus, the Korean 
government has pursued a green hydrogen economy for economic growth, energy security, and an environment that aligns with domestic demands [19].

The purposes of the Korean Green New Deal are sustainability and regional equality. Many scholars have emphasized that the major global Green New Deal initiatives, including those of the US (February 2019) and the EU (December 2019), are climate-oriented economic-stimulating policies that can improve investments, with beneficial economic output and jobs in the near future. These initiatives can also be the basis for the long-term innovation and economic development that correspond to environmental constraints. Thus, the initiatives reduce the gap between the regional inequalities within a country or those between countries [20-22]. As aforementioned, the Korean Green New Deal that was announced on 14 July 2020, as well as the "Hydrogen Economy Roadmap" (January 2019), have announced the dual goals of considerably enhancing the hydrogen economy, and alleviating the resultant regional inequality within the country $[8,23]$.

Following the Hydrogen Economy Roadmap (Figure 1) [15], the government instituted the Hydrogen Economy Council, which was led by the Prime Minister and comprised of eight ministries, including those of Trade, Industry, and Energy (MOTIE); Economy and Finance(MOEF); Interior and Safety (MOIS); Science and ICT (MSIT); Environment (MOE); Land, Infrastructure, and Transport (MOLIT); Oceans and Fisheries (MOF); and SMEs and Startups (MSS). Additionally, the government has instituted five committees of hydrogen experts to foster the research and development (R\&D) collaboration between academic institutes, companies, and organizations since 2021. The five committees consist of production, storage/transportation, utilization for transportation, utilization for energy, and safety/infrastructure committees. The heads of the committees lead $\sim 70$ experts cut across academia, research institutes, and industries to divide a target domain into smaller segments for detailed analyses, after which they can propose the research fields for future investment.

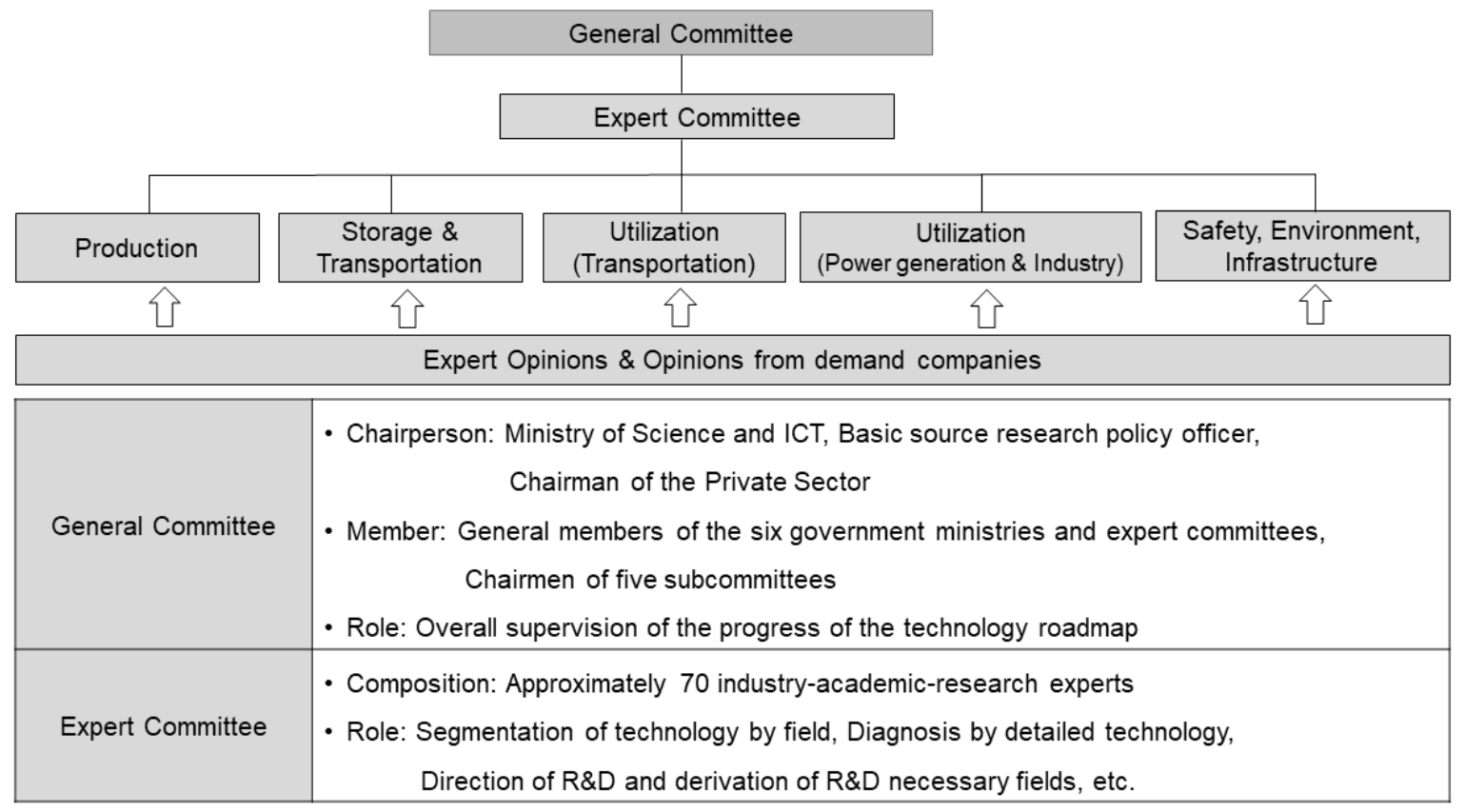

Figure 1. Structure of the strategy committee for the Korean hydrogen economy [15].

The Hydrogen Economy Roadmap of Korea is aimed at expanding the domestic production of hydrogen FCEVs in the transportation industry to 35,000 units by 2022 and 65,000 on South Korean roads. The prices of hydrogen vehicles are expected to compete with those of vehicles employing internal combustion engines, with $5 \times 10^{5}-\mathrm{km}$ durabilities, for 40 million won (USD 41,000) by 2025. For personal transportation, the roadmap includes the introduction of 80,000 hydrogen taxis and 40,000 hydrogen buses 
by 2040. It also includes the introduction of 30,000 hydrogen trucks over the same period for the transportation of freight. Similar to the adoption of electric vehicles, the lack of refueling stations still limits the extensive adoption of hydrogen-powered vehicles. Thus, the roadmap requires the expansion of the number of refueling stations from the present number of 34 to 310 and 1200 in 2022 and 2040, respectively. Regarding power generation and supply, the roadmap is aimed at increasing the production from 307.6 MW to $15 \mathrm{GW}$ by 2040 employing FCs. On the basis of the roadmap, $8 \mathrm{GW}$ of the generated power would be channeled to domestic consumption, while $7 \mathrm{GW}$ would be dedicated to exports. Furthermore, the domestic price of a kilogram of hydrogen is expected to drop from 6500-7500 won (USD 5.42-6.25) to 3000 won (USD 2.5) by 2040 [9]. Figure 2 demonstrates that the local government also plans to apply for a prefeasibility study toward establishing specialized hydrogen complexes in different regions, including Incheon (biohydrogen and byproduct hydrogen production), Jeollabuk-do (green hydrogen), Ulsan (hydrogen mobility), Gyeongsangbuk-do (hydrogen FCs), Gyeongsangnam-do (liquid hydrogen production), and Gangwon Province (liquefied hydrogen storage and transportation) [24].

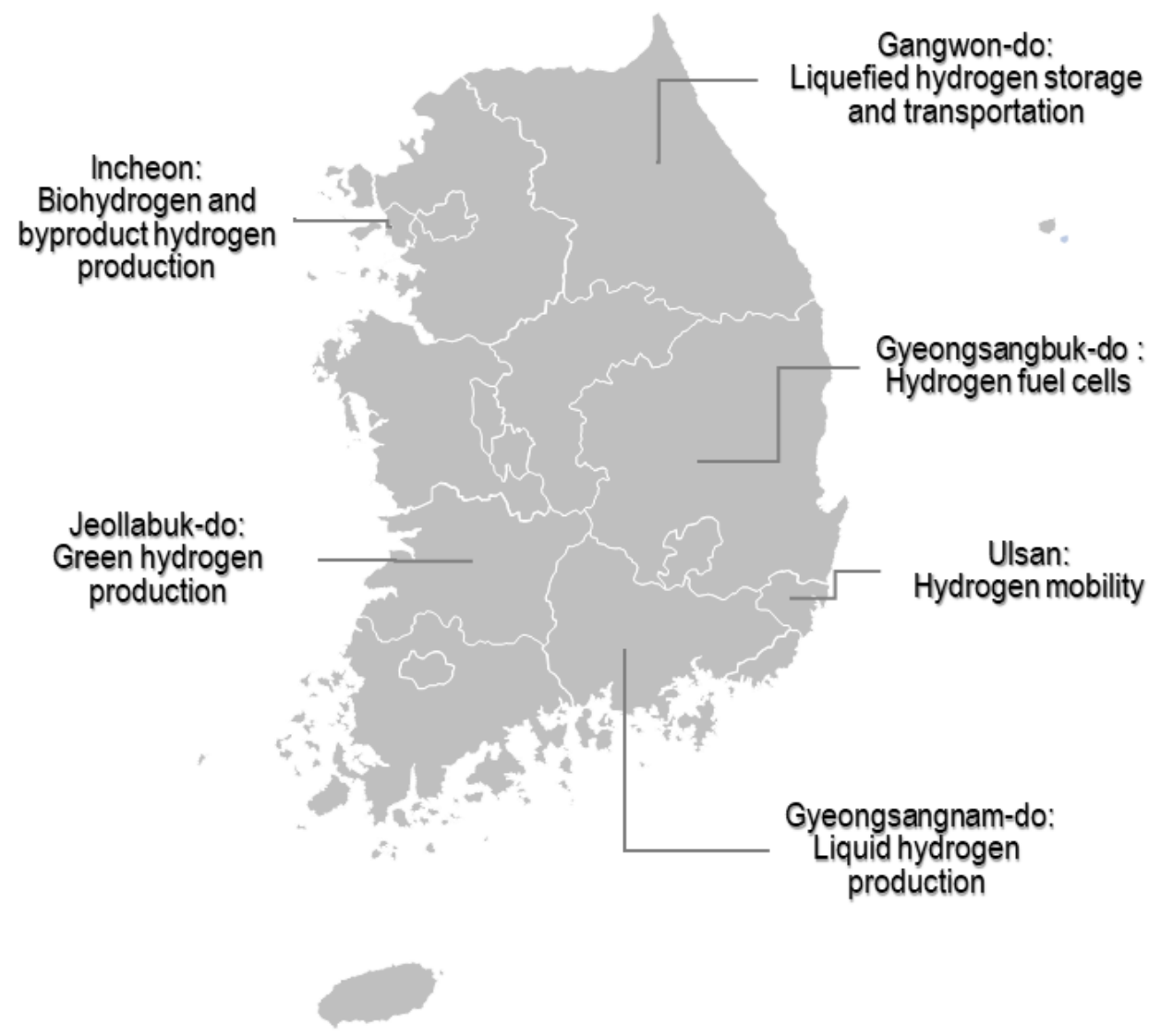

Figure 2. Local specialized regional hydrogen complexes [24].

\subsubsection{Value Chain of the Hydrogen Economy}

The hydrogen economy depends mainly on the clean and efficient production of hydrogen, its storage on the supply side, and the commercial utilization of the energy that is generated across the hydrogen value chain on the demand side $[4,7,25]$. Figure 3 demonstrates that the value chain of the hydrogen economy in Korea is thus: production-storage and transportation-utilization $[7,15]$. This concept of the hydrogen economy has been adopted by many scholars [2,7,26-28]. Based on the definition of a hydrogen economy [28], many hydrogen-production pathway technologies are being explored and developed for the production of hydrogen. Broadly, these include technologies for tapping into fossil resources via carbon capture, utilization, and storage (CCUS), extracting hydrogen from biomass and waste-stream resources, and splitting water [28]. The energy content of hydro- 
gen is nearly three times that of gasoline per unit of mass, although the volumetric energy density of hydrogen gas is low, posing a challenge to storing it in compact containers. To overcome this challenge, hydrogen is generally stored as a gas or cryogenic liquid via physical processes. It can also be stored via material-based processes by which it is incorporated with chemical compounds. To exhibit many applications, multiple technological pathways might be incorporated to transport hydrogen in different forms (as a gas via pipelines and high-pressure tube trailers, as a liquid via tanker trucks, and in chemical hydrogen carriers). Thus, there are four main media for transporting hydrogen on a large scale: gaseous tube trailers, liquid tankers, pipelines (for gaseous hydrogen), and chemical hydrogen carriers [2]. Hydrogen is an energy carrier that is produced from energy and feedstocks, such as water, biomass, natural gas, coal, oil, and wastes. To be valuable, the energy content of hydrogen must be converted into different forms, such as electricity or heat. This conversion can be accomplished through an electrochemical process employing a FC. A FC utilizes the chemical energy of fuels, such as natural or synthetic gas and hydrogen, to produce electricity and thermal energy. FCs can be more efficient compared with internal combustion engines because the electrochemical reactions therein can directly generate electricity. FCs can employ many types of fuels and feedstocks and can serve as the power source for several applications across different sectors, such as the transportation, power-generation, and the industrial and manufacturing sectors [28].

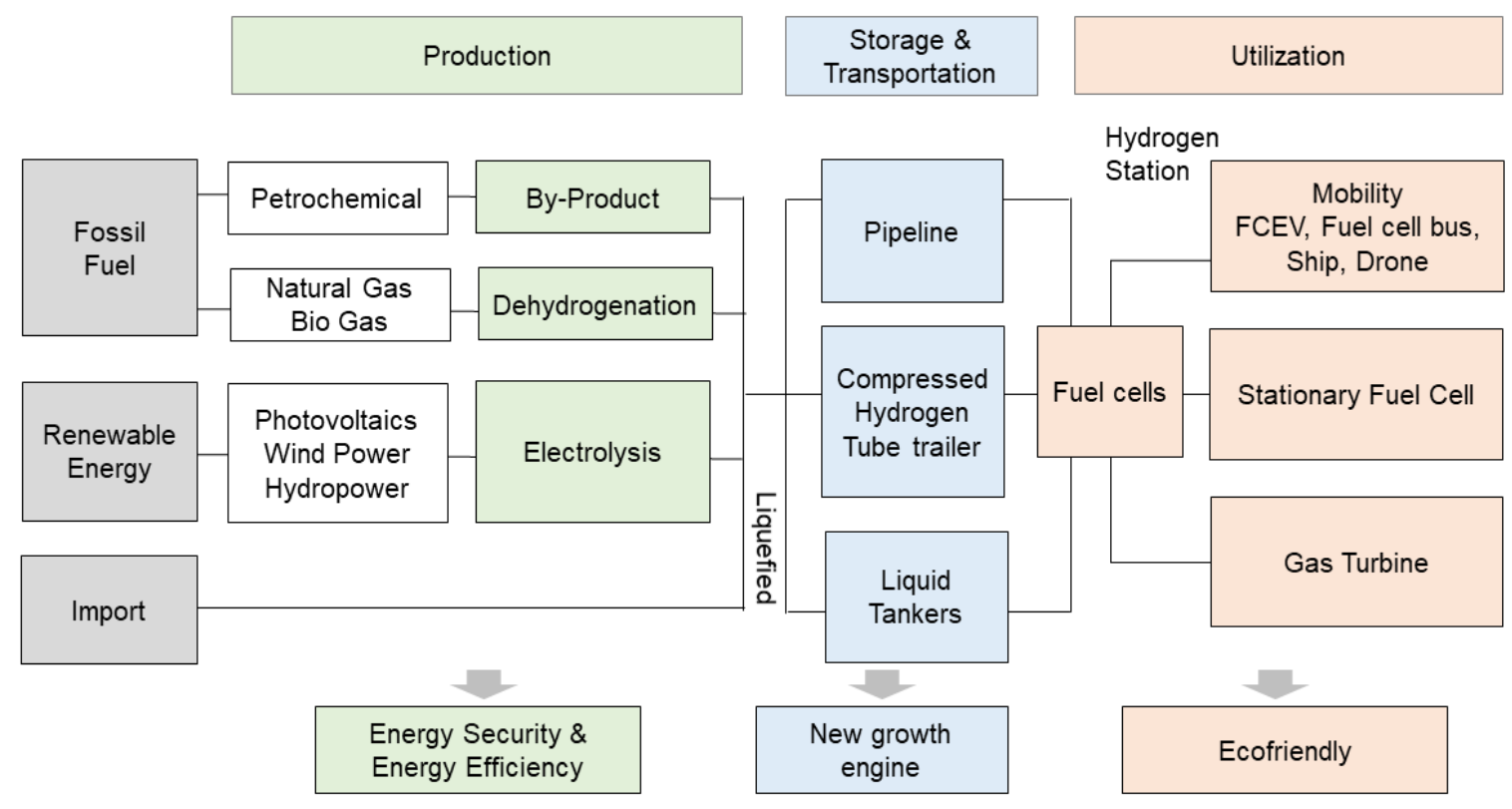

Figure 3. Value chain of the hydrogen economy $[7,15,28]$.

1.1.3. Limitations of the Research on the Hydrogen Economy and Significance of a Systematic Framework for Implementing the Strategy

The review of related literature revealed that there are two broad branches for researching the hydrogen economy. One is related to the investigation of the present status of the hydrogen economy and its roadmaps, and it recommends some policies to boost the growth of the hydrogen economy $[2,4,5,9,10,18,20,27,29,30]$.

On the basis of the specific development plans, as well as the detailed technological roadmaps, of most developed countries (Japan, the US, China, and the EU) for achieving competitive hydrogen economies via cost-effective paths, it is generally agreed that the hydrogen economy is key to promoting sustainable development through energy conservation and system integration employing clean and renewable energies [10,26]. The ultimate goal of these plans, or roadmaps, is green hydrogen regarding climate impact. Although these countries have been investing since the last decade, there are still many unresolved 
issues related to the high cost of producing hydrogen, as well as to its low energy efficiency $[18,26,27]$. Inevitably, these governments must invest in R\&D to achieve reasonable performance and cost targets, as well as generate supply and demand chains for clean hydrogen by developing new infrastructures, reconverting natural-gas pipeline systems, creating new hydrogen markets, and transitioning grey hydrogen industrial sectors toward employing low-carbon hydrogen $[4,9,27]$. Further, the coordination between different stakeholders must be strengthened $[4,5,27]$. In particular, the ambitious transition into a hydrogen economy requires close collaboration between the central and local governments to coherently pursue the strategies or policies [5]. This collaboration can be facilitated by sharing information about a hydrogen-related research landscape [31].

The other approach involves focusing on the value chain of the hydrogen economy from an infometrics perspective (bibliometrics and scientometrics), which is based on a paper and/or patent [1,32-36], or from the evaluation of green energy sources [37-39]. Some scholars have presented future research directions by investigating the evolution of hydrogen research regarding production [1,33,40,41], storage/transportation [33,34,42], and utilization $[35,36,43-47]$, as discussed in Section 1.1.2. Several studies have revealed the emergence of biohydrogenation, photocatalysis, and water splitting as methods for producing hydrogen from renewable energy sources $[1,33,40,41]$, thus revealing prominent international cooperation among different countries/regions and institutions [42]. Some studies have used data envelopment analysis with fuzzy techniques prioritizing the most efficient and sustainable hydrogen production among green hydrogen resources, including wind, solar, biomass, and geothermal energy [37-39]. Regarding hydrogen storage/transportation, the development of new hydrogen storage materials was identified as a valuable research field focused on reducing the requirements of implementing hydrogen absorption and desorption [42], and requiring investment [34]. Regarding hydrogen utilization, the studies on FCs, including proton-exchange membrane FCs (PEMFCs) [43,45], solid oxide FCs (SOFCs) [44], and microbial FCs (MFCs) [35], which are considered the next-generation power sources, present the information of the researchers, governments, funding authorities, and investors, as well as the potential collaborative research partners, that could tend toward commercialization. Moreover, the current status of FCEV-related research was investigated to identify the main agents that are involved in scientific and technological research to reveal their collaborative relationships [46] and identify potential R\&D opportunities [47].

The decision-making processes for a national R\&D strategy generally involve people from government bodies, academia, research agencies, and industry. It is a prerequisite for representatives of the major actors that determine the directions of strategy planning and investment to be furnished with valuable information that will guide the research coordination policies in order to avoid the duplication of effort and identify the research gaps, as well as overlapping interests and opportunities for partnerships [31,48]. However, the former asserts the normative statement that governments should endeavor to accelerate the transition into a global hydrogen economy via a series of national hydrogen strategies that are based on effective collaborations among many stakeholders, as well as public investments in green hydrogen technologies. Thus, there is no detailed information that can facilitate the decision-making process involving different stakeholders. Conversely, the latter focuses on elucidating the knowledge pattern of specific technological fields, as well as identifying the main research organizations and their collaborative relationships. However, quantitative analyses, which are based on publications or patents, exhibit inherent retrospective and financial limitations. Thus, prominent scholars have emphasized the utilization of funding data as an alternative to R\&D investment [49].

To narrow the limitations of previous studies, a framework is proposed here that offers detailed information on the investment trends that are hydrogen-research-based to propose the direction of future investments, as well as the appropriate organization that can conduct the desired research, and in what hydrogen-related research fields, to accelerate the R\&D cooperation between academic institutes, companies, and organizations. Additionally, this 
study attempts to improve the information quality by considering the R\&D type (spectrum), which comprised basic research, applied research, and experimental development as the collaboration-oriented data that might induce the collaboration of the private sector with universities and R\&D institutes $[48,50]$. To the best of our knowledge, there is no existing study on the status of regional hydrogen-related research. Thus, it is required that the stakeholders in industry, academia, research institutes, as well as the government, offer comprehensive information that combines the status of hydrogen-related nationally funded R\&D activities in 17 regions in Korea. This comprehensive full-cycle R\&D information can provide an overview of the macro-investment status of national hydrogen R\&D. It can be a proposal of investment strategies for regional competitiveness that can reduce regional inequality while accelerating potential public-private cooperation to solve the technological agenda of hydrogen conversion. Further, the comprehensive information can support decision-making toward establishing national science and technology policies and strategies toward achieving the hydrogen economy.

\subsection{Research Purpose and Questions}

To establish an R\&D investment and collaboration framework for the national planning strategy for the Korean transition into a hydrogen economy, the target research domain must be divided into small segments, after which information on the current status and trends of the research segments of the targeted research domains must be afforded to discuss the direction of future research, as well as propose investment-requiring research fields [51]. As remarked by a prior study [52], this procedure is the cornerstone that ensures the strengthening of the coordination among stakeholders by reducing uncertainty regarding the information on the different statuses of different target fields of knowledge, thereby improving the quality of the decision-making process that relates to the national R\&D planning strategy [53]. Thus, this study is aimed at presenting timely, comprehensive, and usable information on the status of R\&D activities toward a hydrogen economy in the spectrum of R\&D and the 17 regions, employing the proposed framework. The primary research questions were as follows:

- $\quad$ Research Question RQ1-1: How much did the Korean government invest in hydrogeneconomy-related technologies between 2015 and 2020?

- $\quad$ Research Question RQ1-2: How much did the Korean government invest in hydrogeneconomy-related technology areas regarding the spectrum of R\&D?

- $\quad$ Research Question RQ1-3: How much did the Korean government invest in the hydrogen economy from a regional perspective?

In addition to understanding the directions of the investment of the Korean government in hydrogen-economy-related technologies, the following research questions were examined:

- $\quad$ Research Question RQ2-1: What are the trends of the investment in hydrogen-economyrelated technologies between 2015 and 2020 ?

- $\quad$ Research Question RQ2-2: What are the trends of the investment in the spectrum of the R\&D of technologies that emerged during this period?

- $\quad$ Research Question RQ2-3: What was the regional distribution of the investment in hydrogen-economy-related technologies?

Finally, the detailed research activities in hydrogen-economy-related fields were comprehensively analyzed to elucidate potential partners who may share the knowledge with other stakeholders, and the following research questions emerged:

- $\quad$ Research Question RQ3-1: what types of organizations (academia, industry, and research institutes) have contributed significantly to hydrogen-economy-related technologies from a regional perspective?

- $\quad$ Research Question RQ3-2: What organizations, which are related to hydrogen-economyrelated technologies, served as transregional collaborative R\&D partners from a regional perspective? 
The remainder of this article is structured as follows: the Materials and Methods section describes the framework and methodology; the Results section presents the comparative results of the research profiling and machine learning analyses; and the Discussion and Conclusion section elaborate the research contributions, implications for practice, and research limitations, thus revealing promising research opportunities for the future.

\section{Materials and Methods}

\subsection{Data Collection and Preprocessing}

This study employed the data of nationally funded R\&D projects, which were obtained from the National Science \& Technology Information Service (NTIS). The data contain the information of 1411 national R\&D projects in Korea between 2015 and 2020 and are internally operated by the Korea Institute of Science and Technology Information (KISTI), which is funded by the MSIT of Korea. The organization name, title, research program name, as well as the abstract of each project, have been translated into English. Under the guidance of experts from universities, research institutes, and industries, the authors of this paper conducted a full search and data collection employing the following keywords, and combinations of their variants during the search query: "grey hydrogen"; "blue hydrogen"; "green hydrogen"; "solid fuel"; "pyrolysis"; "syngas"; "methane"; "natural gas"; "steam"; "plasma"; "gasification"; "CCS"; "carbon dioxide"; "artificial photosynthesis"; "anaerobic digestion"; "photocatalyst"; "photofermentation"; "nuclear"; "water electrolysis"; "PEM"; "MEA"; "alkaline"; "membrane"; "electrode"; "biogas"; "port logistic"; "liquid tank"; "carbon monoxide"; "cryogenic"; "deoxidate"; "turbine"; "natural gas"; "CNG"; "refuel charging station"; "cryogenic"; "liquefaction plant"; and "H2". The dataset is described in Table 1. In total, data were collected from 1939 nationally funded R\&D projects that were related to the hydrogen economy and conducted between 2015 and 2020, based on the search terms in Table 1. Thereafter, 678 additional project data items were added based on the 112 R\&D programs to which the collected data belonged. Experts on the hydrogen economy investigated the relation of each project with the value chain of the hydrogen economy and selected a total data sample comprising 1019 projects to cover the entire dataset as extensively as possible. However, the dataset from NTIS exhibited two critical challenges. The first challenge involved the incorrectness of the addresses of the research organizations that completed the projects. It was essential to categorize the number of projects in each of the 17 regions to elucidate the statuses and trends of government $R \& D$ investment for the hydrogen economy. The other challenge involved the incorrectness of the type of organization, e.g., academia, industry, and research institutes, that completed the projects. For example, KISTI, which was established and run by the government, was categorized as academia or industry. Correcting the organization type was critical to generating a potential collaborative network to support the transition toward a hydrogen economy. Therefore, the address and type of the involved organizations were corroborated, or rectified, as necessary. After canceling out the projects with missing funding information, a final data sample of 955 projects, with a total funding amount of USD 565.7 million, was acquired (Tables 2-4).

To elucidate the disciplinary characteristics of the research fields that corresponded to these nationally funded research projects, the All Science Journal Classification (ASJC) model was employed in the machine learning process by utilizing author keywords in approximately one million articles that were found in Scopus, i.e., the features, as well as the ASJC code that was assigned to each paper, i.e., the labels. Thereafter, according to the similarity, which was calculated based on the ASJC classification model, and the procedures of previous studies [54], three ASJC codes were assigned to each nationally funded research project. The probability of the relevance of each assigned ASJC code was determined based on the title and abstract of the nationally funded research project. Moreover, the $25 \%$ threshold probability was applied to further elucidate the correlation between the assigned ASJC codes and the nationally funded research projects. A conceptual diagram of this process is presented in Figure 4 [54]. 
Table 1. Examples of the data of the public R\&D projects in the Korean R\&D database (NTIS).

\begin{tabular}{|c|c|c|c|c|c|c|c|c|c|c|}
\hline \multirow{2}{*}{ Regions } & \multirow{2}{*}{$\begin{array}{c}\text { Unique } \\
\text { Identification } \\
\text { Number (ID) } \\
\end{array}$} & \multirow{2}{*}{ Organization } & \multirow{2}{*}{$\begin{array}{c}\text { Type of } \\
\text { Organization }\end{array}$} & \multirow{2}{*}{$\begin{array}{l}\text { Research } \\
\text { Program }\end{array}$} & \multirow{2}{*}{$\begin{array}{c}\text { R\&D } \\
\text { Spectrum }\end{array}$} & \multirow{2}{*}{$\begin{array}{c}\text { Funding } \\
\text { (USD) }\end{array}$} & \multicolumn{2}{|c|}{ Project Period } & \multicolumn{2}{|r|}{ Project Contents } \\
\hline & & & & & & & Start Date & End Date & Title & Abstract \\
\hline Daejeon & 1711032627 & $\begin{array}{l}\text { Korea Institute of } \\
\text { Energy Research }\end{array}$ & Institutes & $\begin{array}{l}\text { Climate change } \\
\text { response program }\end{array}$ & $\begin{array}{l}\text { Experimental } \\
\text { development }\end{array}$ & 458,333 & $\begin{array}{l}1 \text { December } \\
2015\end{array}$ & 31 July 2021 & $\begin{array}{l}\text { Development of Next } \\
\text { Generation Alkaline } \\
\text { Electrolyzer }\end{array}$ & $\begin{array}{l}\text { Transition metal-based and Ni-based } \\
\text { composite catalyst characterization and } \\
\text { reaction mechanisms and by identifying } \\
\text { the development ratio of the active } \\
\text { precious metal-based alkaline faucet } \\
\text { HER/OER electrode catalyst pore } \\
\text { structure development of a catalyst } \\
\text { structure of the high specific surface area } \\
\text { and to ensure the stability of the electrode } \\
\text { coating technology developed electrode } \\
\text { efficiency and maximizing reliability over } \\
\text { a long period operation }\end{array}$ \\
\hline $\begin{array}{l}\text { Gyeongsangbuk- } \\
\text { do }\end{array}$ & 1711116180 & $\begin{array}{l}\text { Pohang University } \\
\text { of Science and } \\
\text { Technology }\end{array}$ & Academia & $\begin{array}{l}\text { Climate change } \\
\text { response program }\end{array}$ & $\begin{array}{l}\text { Applied } \\
\text { research }\end{array}$ & 48,333 & 27 July 2018 & $\begin{array}{l}27 \text { February } \\
2023\end{array}$ & $\begin{array}{l}\text { Development of HOR } \\
\text { catalysts for AEMFC } \\
\text { via the introduction of } \\
\text { bi-functional effect and } \\
\text { enhancement of } \\
\text { energetics }\end{array}$ & $\begin{array}{c}\text { The anode catalytic activity: } 1.2 \mathrm{~mA} / \mathrm{cm}^{2} \\
\text { @ 20 mVRHE (100\% compared to the } \\
\text { noble metal catalyst) from M1/NiM2M } 3 \\
\text { M2/M3 candidate composition defined: } \\
\text { RDE-based activity assessment/catalyst } \\
\text { bulk manufacturing process } \\
\text { development/optimized catalytic } \\
\text { synthesis ... }\end{array}$ \\
\hline Ulsan & 1711083099 & $\begin{array}{l}\text { Ulsan National } \\
\text { Institute of Science } \\
\text { and Technology }\end{array}$ & Academia & $\begin{array}{l}\text { Basic research } \\
\text { program }\end{array}$ & Basic research & 247,503 & $\begin{array}{l}31 \text { August } \\
2018\end{array}$ & 1 March 2021 & $\begin{array}{l}\text { Development of } \\
\text { electrochemical } \\
\text { membrane reactor for } \\
\text { hydrogen \& syn gas } \\
\text { fabrication }\end{array}$ & $\begin{array}{c}\text { For the high efficiency of the photovoltaic } \\
\text { conversion: } 1 \text {. Development of new } \\
\text { photocatalytic: experimental and } \\
\text { theoretical methods using DFT } \\
\text { calculations continuously performed in } \\
\text { the search for new photocatalytic } \\
\text { materials ... }\end{array}$ \\
\hline
\end{tabular}

Table 2. Data of nationally funded projects and search terms related to the hydrogen economy.

\begin{tabular}{|c|c|c|c|}
\hline Search Terms & $\begin{array}{l}\text { Time } \\
\text { Period }\end{array}$ & Amount of Raw Data & Number of Data Utilized \\
\hline 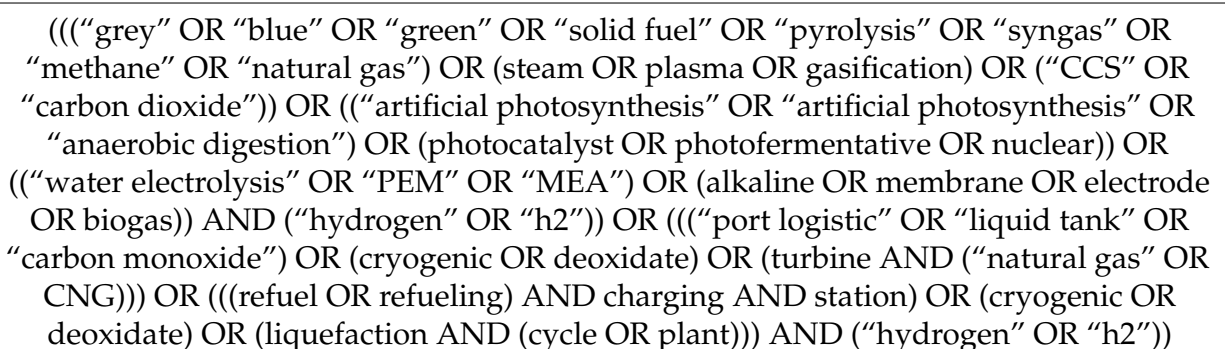 & 2015-2020 & 1939 & 955 \\
\hline
\end{tabular}


Table 3. Number of projects that were nationally funded by the R\&D spectrum.

\begin{tabular}{ccccc}
\hline R\&D Spectrum & Funding (USD Million) & No. Projects & Funding per Project & Funding (\%) \\
\hline Basic research & 169.7 & 422 & 0.4 & $30.0 \%$ \\
Applied research & 95.0 & 161 & 0.6 & $16.8 \%$ \\
Experimental development & 255.1 & 311 & 0.8 & $45.1 \%$ \\
Others & 45.9 & 61 & 0.8 & $8.1 \%$ \\
Total/Average & 565.7 & 955 & 0.6 & $100.0 \%$ \\
\hline
\end{tabular}

Table 4. Number of projects that were nationally funded by regions in South Korea.

\begin{tabular}{ccccc}
\hline Region & Funding (USD Million) & No. Projects & Funding per Project & Funding (\%) \\
\hline Gangwon-do & 1.2 & 2 & 0.6 & $0.2 \%$ \\
Gyeonggi-do & 60.9 & 103 & 0.6 & $10.8 \%$ \\
Gyeongsangnam-do & 22.9 & 44 & 0.5 & $4.0 \%$ \\
Gyeongsangbuk-do & 25.7 & 67 & 0.4 & $4.5 \%$ \\
Gwangju & 2.9 & 21 & 0.1 & $0.5 \%$ \\
Daegu & 1.5 & 16 & 0.1 & $0.3 \%$ \\
Daejeon & 175.5 & 239 & 0.7 & $31.0 \%$ \\
Busan & 28.7 & 75 & 0.4 & $5.1 \%$ \\
Seoul & 66.1 & 121 & 0.5 & $11.7 \%$ \\
Sejong & 0.3 & 7 & 0.0 & $0.0 \%$ \\
Ulsan & 38.0 & 83 & 0.5 & $6.7 \%$ \\
Incheon & 10.7 & 10 & 1.1 & $1.9 \%$ \\
Jeollanam-do & 2.6 & 12 & 0.2 & $0.5 \%$ \\
Jeollabuk-do & 62.5 & 72 & 0.9 & $11.0 \%$ \\
Chungcheongnam-do & 54.5 & 70 & 0.8 & $9.6 \%$ \\
Chungcheongbuk-do & 11.7 & 13 & 0.9 & $2.1 \%$ \\
Total/Average & 565.7 & 955 & 0.6 & $100.0 \%$ \\
\hline
\end{tabular}

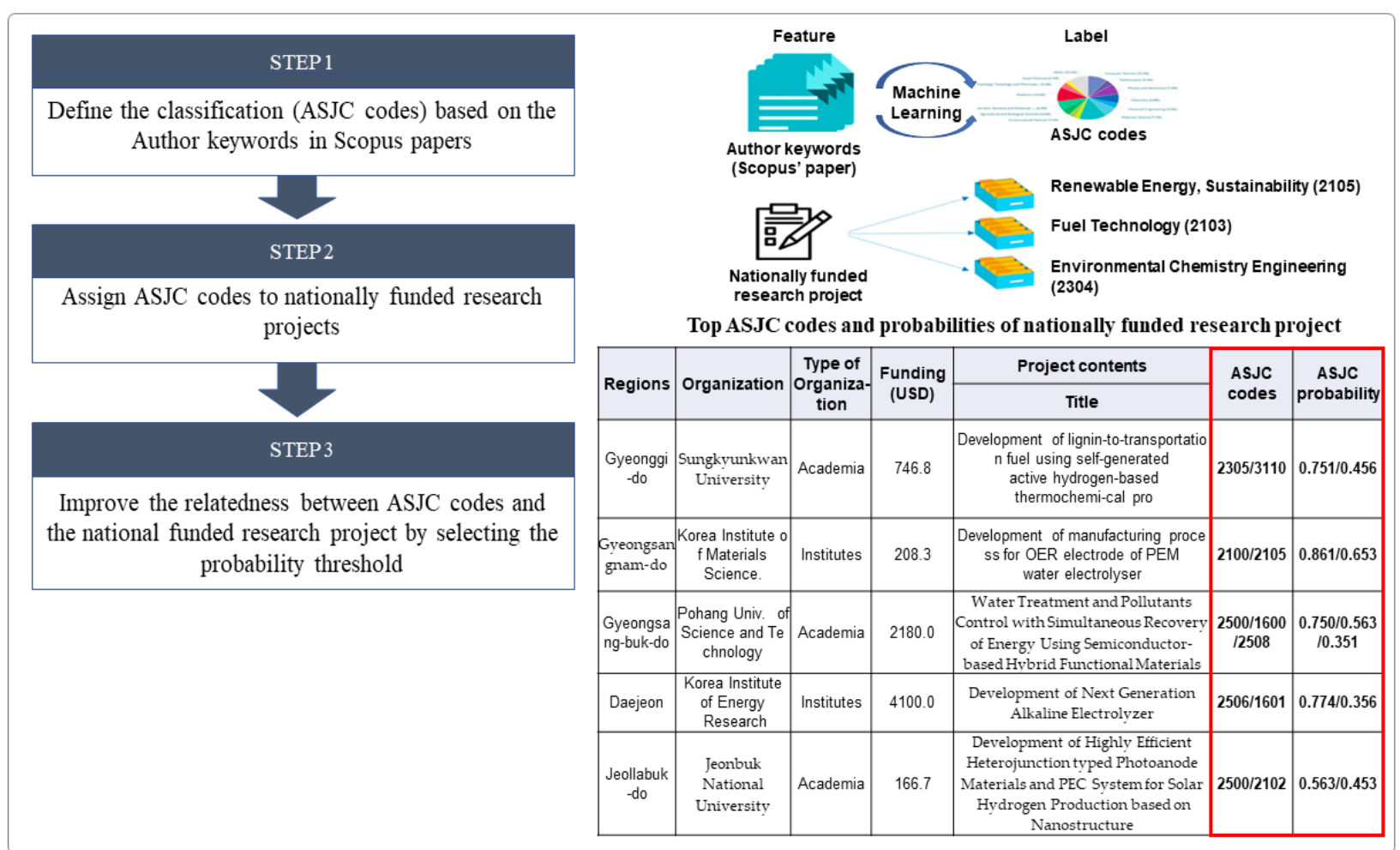

Figure 4. Process of assigning ASJC codes to the nationally funded research projects and improving the correlation between the ASJC codes and the projects [54]. 


\subsection{Clustering Process}

Based on previous studies [51,52,54,55], a co-occurrence technique was employed to identify the hydrogen-economy-related research fields. The number of times the ASJC codes appeared together in a project group revealed the relevance of that project. Particularly, the co-occurrence matrix revealed the number of times that elements $i$ (from the first list), and $j$ (from the second list), appeared together in the text, namely, $i, j=$ ASJC codes. The more often the ASJC codes appeared in the projects, the higher their relevance with the codes.

The network was created based on the number of appearances of ASJC codes in the projects, which was defined by the co-occurrence matrix. All the nodes in the network were drawn according to the titles of the research fields present in the ASJC codes, and the font size indicated the frequency of the co-occurrence of each ASJC code compared with those of the others. By visualizing this network structure, the relationship between the ASJC codes could be elucidated. The mapping and clustering were calculated based on previous studies [51,52,54,55].

The resolution parameter $(\gamma>0)$ determines the level of the details of the clustering, i.e., the higher the parameter, the larger the number of produced clusters. The number of clusters ranged from $1(\gamma=0.1)$ to $9(\gamma=2.0)$. To analyze the semantic network, nine clusters were selected according to the number and combination of items (the ASJC codes) in each cluster.

\subsection{Defining the Research Fields That Were Related to the Hydrogen Economy}

The hydrogen-economy-related research fields can only be defined by analyzing the titles and abstracts of the R\&D projects, as well as the distribution of the ASJC codes. This analysis is supported by discussions between experts on hydrogen-economy-related research who can provide relevant information and expertise for investigating specific research fields. Therefore, we first assessed the approximate research fields by determining the distribution of the ASJC codes comprising each cluster. Afterward, the titles and abstracts of the R\&D projects in the clusters were identified. Finally, the label of the research field of each cluster was determined. The entire process is presented in Figure 5.

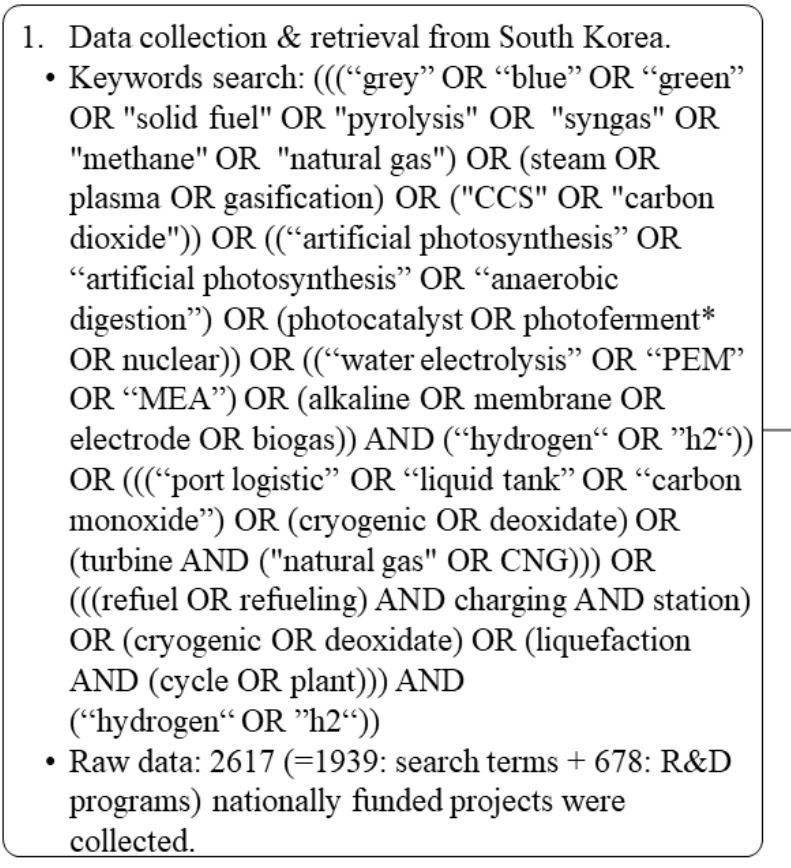

\section{Pre-processing \\ - Correct the error of organizations address and the type (academia, institutes, industry, others) \\ - Removed data of projects with missing funding information. \\ - 955 nationally funded projects were used for further analysis.}

3. Co-occurrence matrix \& clustering analysis.

- Conduct the co-occurrence matrix analysis with all projects data of South Korea using Vantage Point system.

- Derived clusters by VOSViewer system.

4. Defining hydrogen economy-related research fields (Clusters).

- Label individual clusters according to the R\&D project title and abstract and distribution of ASJC codes comparing the cluster, with the help of hydrogen economy-related experts.

Figure 5. Data collection process and analyses of nationally funded global research projects that are related to the hydrogen economy. 


\section{Results}

\subsection{Nationally Funded Projects Relating to the Hydrogen Economy}

The visualization of the network of hydrogen-economy-related research fields is presented in Figure 6. Here, the items/nodes, which were treated as the objects of interest, were the research fields, i.e., the ASJC codes. The links, which indicate the relationship between two items, refer to the co-occurrence links between the research fields. The strength/weight of a link indicates the number of projects in which the two research fields appeared. The label and circle sizes of each research field were determined by the weight of the field. Thus, the higher the weight of a research field, the larger its label and circle. The characteristics of each research field were determined by the cluster to which it belonged.

The research fields that are related to the hydrogen economy were divided into nine clusters. After considering the titles and abstracts of the projects, their representative research fields, and the related keywords, the ultimate goals of each field were determined as follows:

- Cluster 1. Hydrogen Production (hydrogen infrastructure and safety): research on the materials, parts, and measurement standards for hydrogen safety and reliability, i.e., hydrogen safety standards and material metrology.

- Cluster 2. Hydrogen Utilization (hydrogen fueling stations): research on hydrogen refueling station systems for FCEVs, i.e., chillers and dispensers.

- Cluster 3. Hydrogen Storage \& Transportation (hydrogen transportation): research on hydrogen pipeline delivery infrastructure or liquefied-hydrogen carrier ships, i.e., 450 bar tube trailers and liquid-hydrogen storage tanks.

- Cluster 4. Hydrogen Production (green hydrogen production): research on the production of hydrogen that satisfies the low-carbon threshold and is generated from renewable energy sources, such as solar or wind, i.e., alkaline water electrolysis and photoelectrochemical water splitting.

- Cluster 5. Hydrogen Production (blue hydrogen production): research on the production of hydrogen that satisfies the low-carbon threshold via carbon capture and storage (CCS) for the GHGs that were produced during the production of grey hydrogen but generated via nonrenewable energy sources, i.e., CCS and thermal plasma reforming.

- Cluster 6. Hydrogen Utilization (hydrogen demonstration): research on the demonstration of regional hydrogen cities, i.e., hydrogen grids and hydrogen gas turbines.

- Cluster 7. Hydrogen Utilization (power-to-x): Research on the conversion of the power that was generated from solar and wind sources to different energy carriers for consumption in different sectors or reconversion into power, i.e., power-to-hydrogen, power-to-methane.

- Cluster 8. Hydrogen Utilization (FCs): research on advanced materials for FCs and FC power systems, i.e., PEMFCs and SOFCs.

- Cluster 9. Hydrogen Storage \& Transportation (hydrogen storage) research on hydrogen storage technologies, including compressed hydrogen gas tanks, liquid hydrogen tanks, cryogenic compressed hydrogen, metal hydrides, high-surface-area adsorbents, and chemical hydrogen storage materials, i.e., liquid organic hydrogen carriers (LOHCs) and complex hydrides.

The nine clusters indicated the value chain of the hydrogen economy, as explained in Section 1.1.2 $[7,28]$. In order to analyze the value chain of the hydrogen economy in detail, the nine clusters were designated into three categories: (1) hydrogen production: blue and green hydrogen productions (Clusters 5 and 6 ) and hydrogen infrastructure and safety (Cluster 1); (2) hydrogen storage and transportation: hydrogen transportation (Cluster 3) and storage (Cluster 9); and (3) hydrogen utilization: power-to-x (Cluster 7), hydrogen demonstration (Cluster 6), hydrogen fueling stations (Cluster 2), and FCs (Cluster 8). In the following subsections, the statuses or trends of the nationally funded projects toward the hydrogen economy in Korea were presented regarding the technology clusters, R\&D spectrum, and organizations of the regions. 


\begin{tabular}{|c|c|c|c|c|c|c|c|}
\hline Label & Code & ASJC & Cluster & Label & Code & ASJC & Cluster \\
\hline \multirow{4}{*}{$\begin{array}{l}\text { Hydrogen } \\
\text { infrastructure } \\
\text { \& safety }\end{array}$} & 2304 & Environmental Chemistry & \multirow{4}{*}{1} & \multirow{4}{*}{$\begin{array}{l}\text { Hydrogen } \\
\text { fueling } \\
\text { stations }\end{array}$} & 1502 & Bioengineering & \multirow{4}{*}{2} \\
\hline & 1601 & Chemistry (miscellaneous) & & & 1902 & Atmospheric Science & \\
\hline & 2300 & General Environmental Science & & & 2606 & Control and Optimization & \\
\hline & 1504 & Chemical Health and Safety & & & 2506 & Metals and Alloys & \\
\hline
\end{tabular}

\begin{tabular}{|c|c|c|c|}
\hline Label & Code & ASJC & Cluster \\
\hline \multirow{3}{*}{$\begin{array}{c}\text { Hydrogen } \\
\text { transportation }\end{array}$} & 2503 & Ceramics and Composites & \multirow{3}{*}{3} \\
\cline { 2 - 3 } & 2306 & Global and Planetary Change & \\
\cline { 2 - 3 } & 1602 & Analytical Chemistry & \\
\cline { 2 - 3 } & 2101 & Energy (miscellaneous) & \\
\hline
\end{tabular}

\begin{tabular}{|c|c|c|c|}
\hline Label & Code & ASJC & Cluster \\
\hline \multirow{3}{*}{$\begin{array}{c}\text { Green } \\
\text { hydrogen } \\
\text { production }\end{array}$} & 2105 & Renewable Energy, Sustainability & 4 \\
\cline { 2 - 4 } & 2100 & General Energy & \\
\cline { 2 - 4 } & 1507 & Fluid Flow and Transfer Processes & \\
\cline { 2 - 4 } & 3104 & Condensed Matter Physics & \\
\hline
\end{tabular}

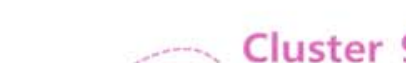

\begin{tabular}{|c|c|c|c|}
\hline Label & Code & ASJC & Cluster \\
\hline \multirow{3}{*}{$\begin{array}{c}\text { Grey \& Blue } \\
\text { Hydrogen } \\
\text { production }\end{array}$} & 1508 & Process Chemistry and Technology & \\
\cline { 2 - 4 } & 1501 & Chemical Engineering (miscellaneous) & \multirow{2}{*}{5} \\
\cline { 2 - 3 } & 2213 & Safety, Risk, Reliability and Quality & \\
\cline { 2 - 4 } & 1505 & Colloid and Surface Chemistry & \\
\hline
\end{tabular}

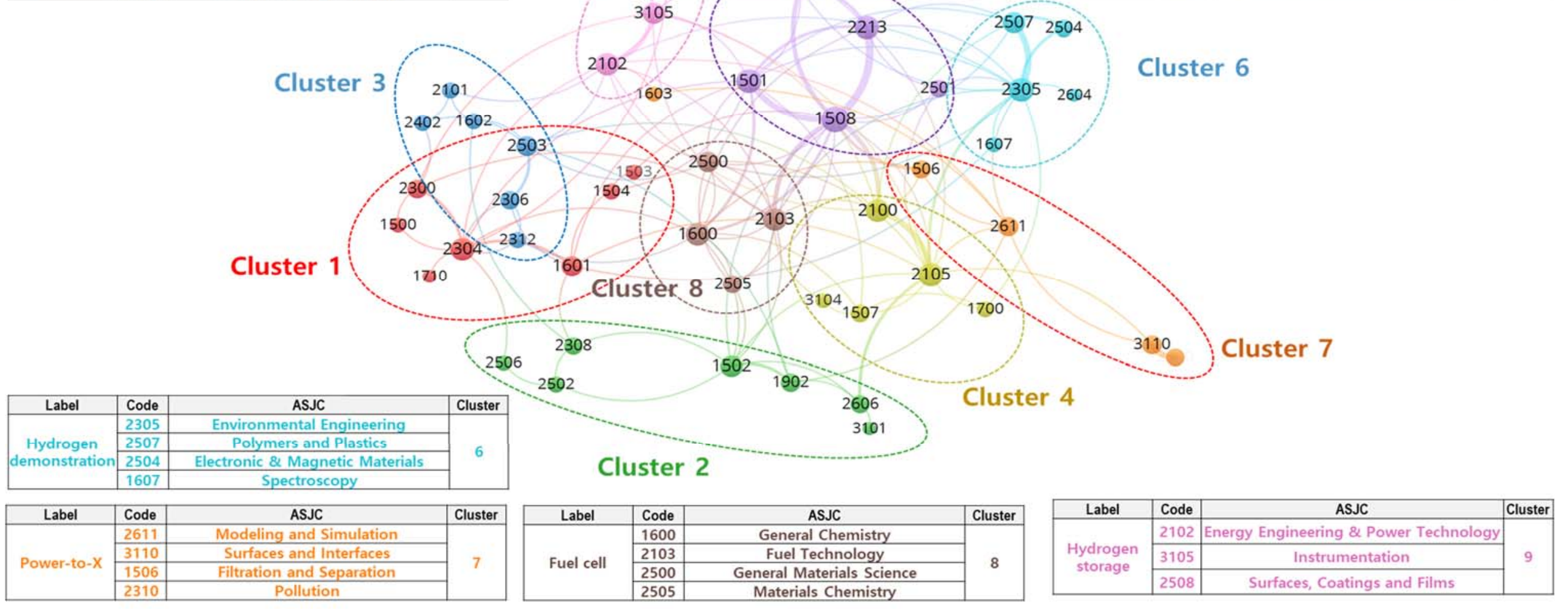

Figure 6. Research field related to the hydrogen economy. 


\subsection{Status of Government Investment in the Hydrogen Economy}

3.2.1. Overall Investment Status of the Government-Funded Projects toward the Hydrogen Economy

The Korean government invested USD 565.7 million in the hydrogen economy between 2015 and 2020. Figure 6 presents the total amount that was expended as research funds for the research on the national hydrogen economy regarding the value chain and its technical clusters. More than half of the national research budget was invested in the hydrogen production sector (USD 320 million, 56.6\%), followed by the hydrogen utilization sector (USD 162.9 million, 28.8\%), and the hydrogen storage and transportation sector (USD 82.5 million, 14.5\%). In the technology clusters of the value chain, the hydrogen production sector invested USD 139.8 million (24.7\%) in green hydrogen production, USD 117.7 million (19.7\%) in blue hydrogen production, and USD 68.9 million (12.2\%) in hydrogen infrastructure and safety. The hydrogen utilization sector invested USD 60.9, 49.7, 8.8, 32.4, and 19.8 million in FCs, hydrogen fueling stations, hydrogen demonstrations, and power-to-x, accounting for $10.8,8.8,5.7$, and $3.5 \%$ of the budget, respectively. In the hydrogen storage and transportation sector, $12.5 \%$ and $2.1 \%$ of the funds were invested in hydrogen storage (USD 70.8 million) and transportation (USD 11.7 million), respectively.

Table 5 presents the total amount of funding for the national hydrogen economy by value chain, by technology cluster in the value chain, and by the spectrum of R\&D. The investment by R\&D spectrum was USD 169 million for the basic research, USD 95 million for applied research, and USD 255.1 million for experimental development. In the hydrogen production sector, the basic research stage on blue hydrogen and green hydrogen production invested over USD 50 million, but investment in the experimental development stage was relatively limited to approximately USD 30 million. In the hydrogen storage and transportation sector, the experimental development stage of the hydrogen storage sector invested USD 37.5 million, while the hydrogen transportation sector invested a relatively small amount of USD 3.1 million. Basic research and applied research stages in the hydrogen storage and transportation sector have relatively little investment compared to the hydrogen production and hydrogen utilization sector. In the hydrogen utilization sector, USD 41.3 million and USD 30.4 million were invested in the experimental development stage of the hydrogen fueling stations and fuel cells, respectively, but funding investments in the basic research and applied research stages were relatively small compared to the experiment development stage. The experimental development stages of the hydrogen demonstration and power-to-x invested USD 20.6 million and USD 15.6 million, respectively.

Figure 7 presents the present state of the investment in the hydrogen economy in 17 regions in Korea. As observed, Daejeon was the most funded region, accounting for $31 \%$ of the R\&D investment (USD 175.5 million), and this indicates that the government's investment was concentrated in Daejeon. Subsequently, Seoul (USD 66.1 million, 11.7\%), Jeollabuk-do (USD 62.5 million, 11\%), Gyeonggi-do (USD 60.9 million, 10.8\%), Chungcheongnam-do (USD 54.5 million, 9.6\%), Ulsan (USD 38 million, 6.7\%), Busan (USD 28.7 million, 5.1\%), Gyeongsangnam-do (USD 22.9 million, 4.0\%), Chungcheongbuk-do (USD 11.7 million, 2.1\%), and Incheon (USD 10.7 million, 1.9\%) were funded in that order. The information on the proportion of the investments in the hydrogen-economy-related research in the regions can afford various stakeholders the opportunity to set the direction, as well as consider appropriate $R \& D$ investments for improving the regions. 

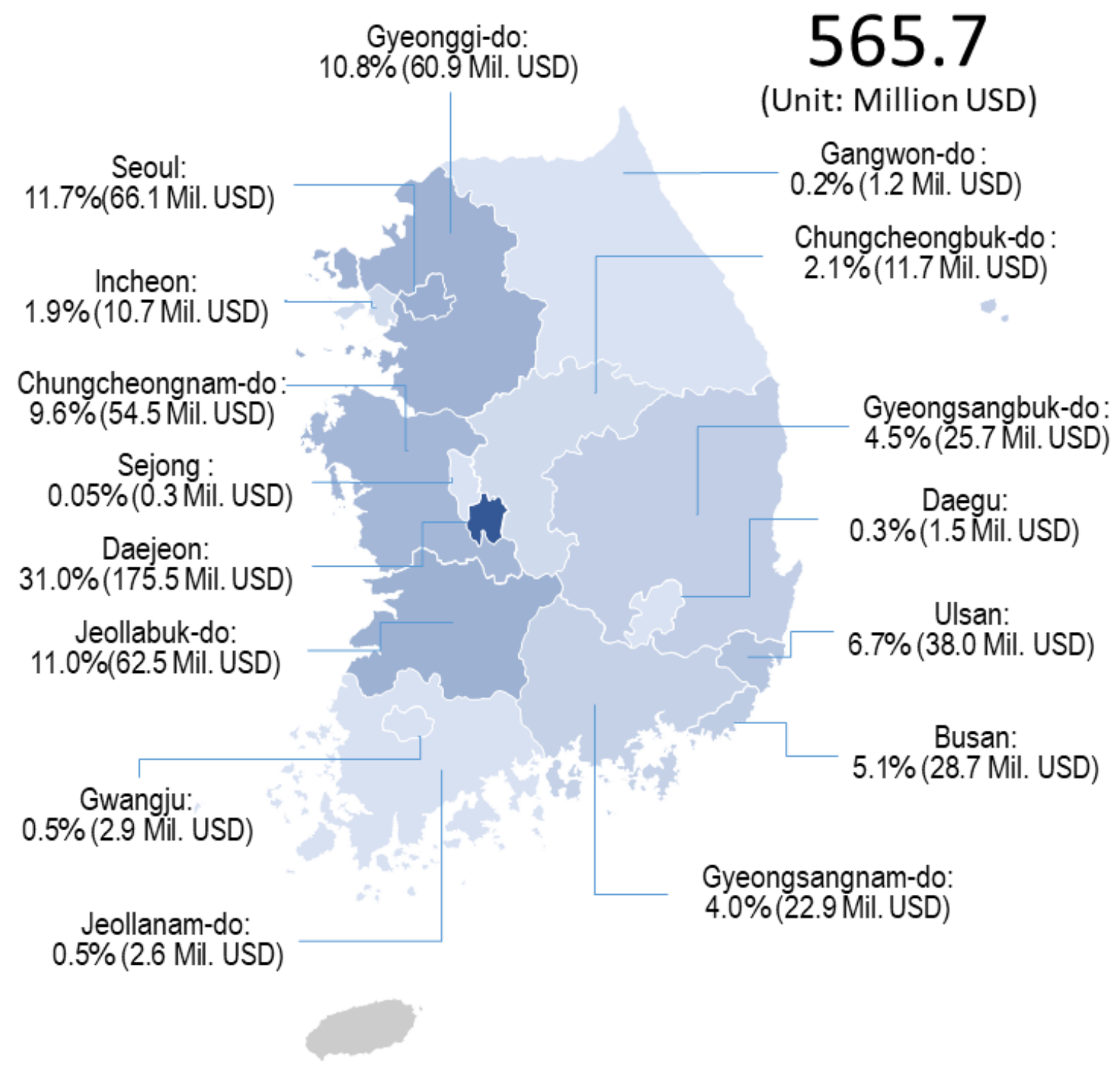

Figure 7. The proportion of public investment in the hydrogen economy in the 17 regions.

3.2.2. Status and Trends of Government-Funded Projects According to the Technology Clusters and R\&D Spectrum

The compounded annual growth rates (CAGR) of the technology segments between 2015 and 2020 are presented in Table 6. The hydrogen utilization sector was the fastest growing value chain. Particularly, the power-to-x increased from USD 0.4 million in 2016 to USD 7.6 million in 2019, accounting for a CAGR of $123.3 \%$. Additionally, the hydrogen fueling stations and FCs exhibited steady growths with CAGRs of $72.2 \%$ and $16.4 \%$ from USD 0.9 and 6.6 million in 2015, to USD 13.1 and 14.1 million in 2019, respectively. These findings reflect the goal of the government to prepare for the expansion of domestic hydrogen vehicle markets by investing intensively in the development of the technologies that are related to hydrogen fueling stations and FCs. Moreover, in the hydrogen production sector, the blue and green hydrogen production technology clusters received investments of USD 18.9 and USD 21.1 million in 2015, respectively, and grew gradually, although their CAGRs exhibited decreasing trends from 2018. Conversely, the hydrogen infrastructure and safety sector exhibited a steady increase, with a CAGR of $28.3 \%$ from USD 4.8 million in 2015 to USD 15.1 million in 2019. Hydrogen storage exhibited a gradual decrease in the CAGR, although hydrogen transportation maintained its rapid growth with a CAGR of $54.5 \%$. Although the proportions of the blue and green hydrogen productions in the hydrogen production sector accounted for the highest total funding (Figure 8), the trends 
of the investment budgets for blue and green hydrogen productions were reduced over the year, indicating that more $R \& D$ public investments are required in the hydrogen production sector for the successful transition to the hydrogen economy.

Table 5. The scale of the funding of the value chain based on the spectrum of the R\&D.

\begin{tabular}{|c|c|c|c|c|c|c|}
\hline $\begin{array}{l}\text { Value Chain } \\
\text { Sector }\end{array}$ & Technology Cluster & $\begin{array}{c}\text { Basic } \\
\text { Research }\end{array}$ & $\begin{array}{l}\text { Applied } \\
\text { Research }\end{array}$ & $\begin{array}{l}\text { Experimental } \\
\text { Development }\end{array}$ & Others & Total \\
\hline \multirow{4}{*}{$\begin{array}{l}\text { Hydrogen } \\
\text { production }\end{array}$} & $\begin{array}{l}\text { Blue hydrogen } \\
\text { production }\end{array}$ & 57.5 & 4.6 & 34.9 & 14.7 & 111.7 \\
\hline & $\begin{array}{l}\text { Green hydrogen } \\
\text { production }\end{array}$ & 59.0 & 32.1 & 39.1 & 9.5 & 139.8 \\
\hline & $\begin{array}{l}\text { Hydrogen infrastructure } \\
\text { \& safety }\end{array}$ & 21.3 & 10.9 & 32.5 & 4.1 & 68.9 \\
\hline & Sum & 137.8 & 47.6 & 106.5 & 28.4 & 320.3 \\
\hline \multirow{3}{*}{$\begin{array}{l}\text { Hydrogen storage } \\
\text { and transportation }\end{array}$} & Hydrogen transportation & - & 7.4 & 3.1 & 1.2 & 11.7 \\
\hline & Hydrogen storage & 12.1 & 17.7 & 37.5 & 3.5 & 70.8 \\
\hline & Sum & 12.1 & 25.1 & 40.6 & 4.7 & 82.5 \\
\hline \multirow{5}{*}{$\begin{array}{l}\text { Hydrogen } \\
\text { utilization }\end{array}$} & Power-to-X & 2.6 & 1.7 & 15.6 & - & 19.8 \\
\hline & $\begin{array}{c}\text { Hydrogen } \\
\text { demonstration }\end{array}$ & 2.3 & 0.7 & 20.6 & 8.8 & 32.4 \\
\hline & $\begin{array}{l}\text { Hydrogen fueling } \\
\text { stations }\end{array}$ & 1.6 & 4.0 & 41.3 & 2.9 & 49.7 \\
\hline & Fuel cell & 13.4 & 15.9 & 30.4 & 1.2 & 60.9 \\
\hline & Sum & 19.8 & 22.3 & 108.0 & 12.8 & 162.9 \\
\hline \multicolumn{2}{|c|}{$\begin{array}{c}\text { Total sum } \\
\text { Fund (Unit: USD million) }\end{array}$} & 169.7 & 95.0 & 255.1 & 45.9 & 565.7 \\
\hline
\end{tabular}

Table 6. Trends of the time serial scale of the nationally funded project by clusters.

\begin{tabular}{|c|c|c|c|c|c|c|c|c|c|}
\hline $\begin{array}{l}\text { Value Chain } \\
\text { Sector }\end{array}$ & Technology Cluster & 2015 & 2016 & 2017 & 2018 & 2019 & 2020 & Total & $\begin{array}{c}15-20 \\
\text { CAGR }\end{array}$ \\
\hline \multirow{3}{*}{$\begin{array}{l}\text { Hydrogen } \\
\text { production }\end{array}$} & $\begin{array}{l}\text { Blue hydrogen } \\
\text { production }\end{array}$ & 18.9 & 18.5 & 24.2 & 24.8 & 17.6 & 7.8 & 111.7 & $-16.2 \%$ \\
\hline & $\begin{array}{l}\text { Green hydrogen } \\
\text { production }\end{array}$ & 21.1 & 25.8 & 24.3 & 23.0 & 29.1 & 16.6 & 139.8 & $-4.7 \%$ \\
\hline & $\begin{array}{c}\text { Hydrogen } \\
\text { infrastructure \& safety }\end{array}$ & 4.8 & 10.8 & 11.3 & 10.4 & 15.1 & 16.5 & 68.9 & $28.3 \%$ \\
\hline \multirow{2}{*}{$\begin{array}{l}\text { Hydrogen } \\
\text { storage and } \\
\text { transportation }\end{array}$} & $\begin{array}{l}\text { Hydrogen } \\
\text { transportation }\end{array}$ & - & 0.9 & 0.8 & 1.5 & 3.6 & 4.9 & 11.7 & $54.5 \%$ \\
\hline & Hydrogen storage & 15.8 & 12.6 & 10.4 & 9.1 & 13.7 & 9.1 & 70.8 & $-10.4 \%$ \\
\hline \multirow{4}{*}{$\begin{array}{l}\text { Hydrogen } \\
\text { utilization }\end{array}$} & Power-to-X & - & 0.4 & 0.9 & 0.8 & 7.6 & 10.1 & 19.8 & $123.3 \%$ \\
\hline & $\begin{array}{c}\text { Hydrogen } \\
\text { demonstration }\end{array}$ & 4.5 & 6.6 & 10.3 & 4.8 & 0.7 & 5.5 & 32.4 & $4.0 \%$ \\
\hline & $\begin{array}{l}\text { Hydrogen fueling } \\
\text { stations }\end{array}$ & 0.9 & 5.8 & 6.4 & 9.1 & 13.1 & 14.3 & 49.7 & $72.2 \%$ \\
\hline & Fuel cell & 6.6 & 15.9 & 12.4 & 5.9 & 6.0 & 14.1 & 60.9 & $16.4 \%$ \\
\hline \multicolumn{2}{|c|}{$\begin{array}{c}\text { Total sum } \\
\text { (Unit: USD million) }\end{array}$} & 72.6 & 97.3 & 101.0 & 89.3 & 106.6 & 99.0 & 565.7 & $6.4 \%$ \\
\hline
\end{tabular}




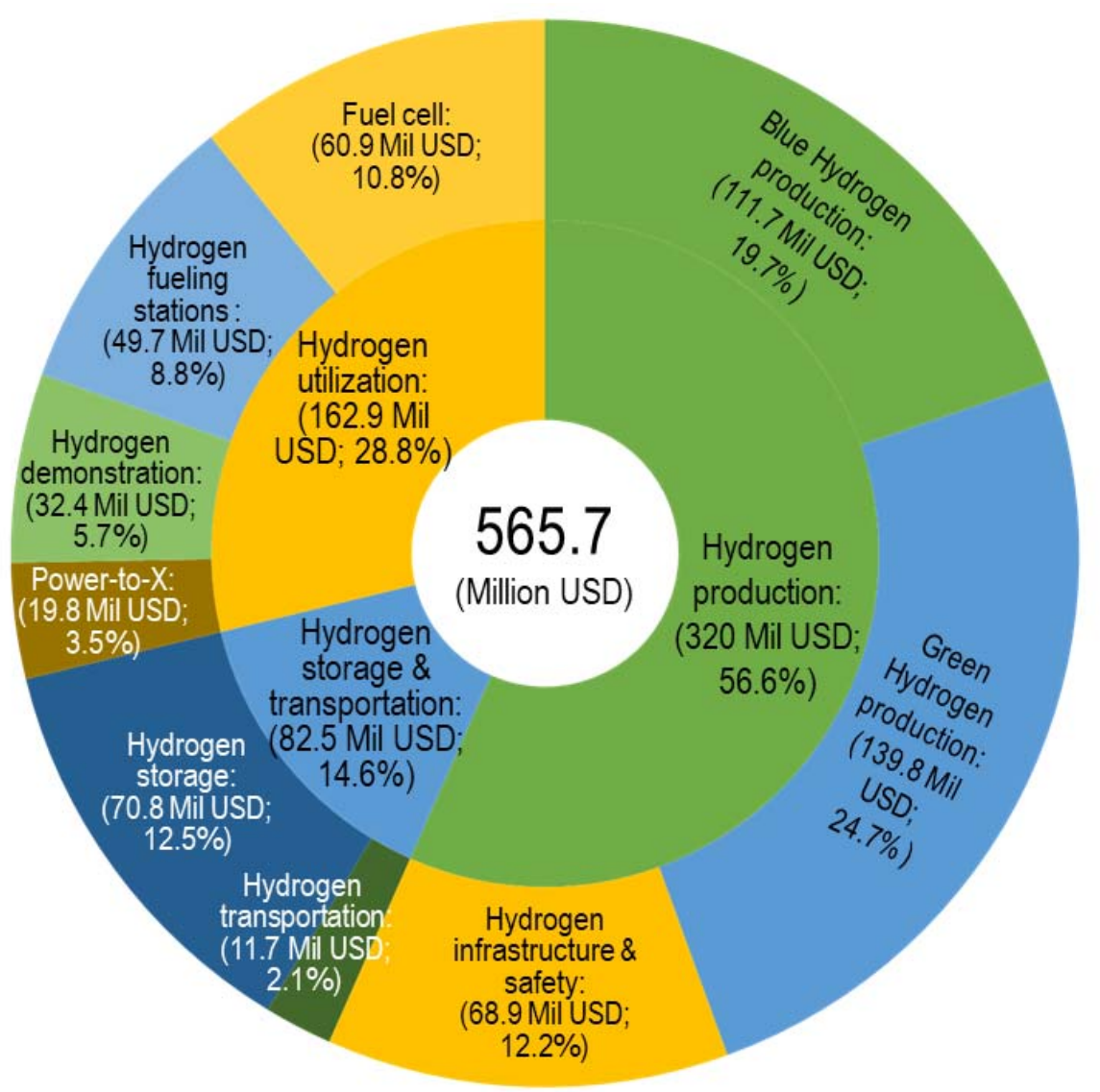

Figure 8. The scale of the funding based on the value chain of the hydrogen economy.

Further, the trends of the changes were investigated based on the year and types of hydrogen-economy-related technologies between 2015 and 2020. Table 7 presents the changes in the trends of the CAGRs of the investments with regard to the R\&D spectrum of the technology cluster in the value chain. With regard to the hydrogen production sector, the CAGRs exhibited a decreasing trend in all the R\&D spectrum stages, including the basic research, applied research, and experimental development stages for the productions of blue and green hydrogen. As exhibited in Table 6, this is a detailed analysis of the downward trend of the total investment, indicating the decrease in the public funding for core technologies, such as blue and green hydrogen production. In the hydrogen storage and transportation sector, the CAGR with regard to the R\&D spectrum for hydrogen transportation exhibited a gradual increase. However, with regard to hydrogen storage, the CAGR exhibited a decreasing trend in the basic research and experimental development stages. With regard to the hydrogen utilization sector, the CAGR increased steadily in all the R\&D spectrums, from the basic research to the experimental development stages in the technology clusters, such as power-to-x, hydrogen refueling stations, and FCs, indicating that the government's public funds have been intensively channeled to the hydrogen utilization sector, such as to FCs and hydrogen fueling stations, rather than to core technology fields, such as the production of blue and green hydrogen. For the government, it appeared that considerable public funding had been channeled toward the hydrogen production sector. However, it is still too soon to change the national research direction toward the feasibility studies if the current hydrogen price does not compete against fossil-based hydrogen costs effectively. 
Table 7. The scale of the funding of the value chain of the hydrogen economy regarding the R\&D spectrum.

\begin{tabular}{|c|c|c|c|c|c|c|c|c|c|c|}
\hline $\begin{array}{l}\text { Value Chain } \\
\text { Sector }\end{array}$ & Technology Cluster & $\begin{array}{c}\text { R\&D } \\
\text { Spectrum }\end{array}$ & 2015 & 2016 & 2017 & 2018 & 2019 & 2020 & Total & $\begin{array}{c}15-20 \\
\text { CAGR }\end{array}$ \\
\hline \multirow{12}{*}{ 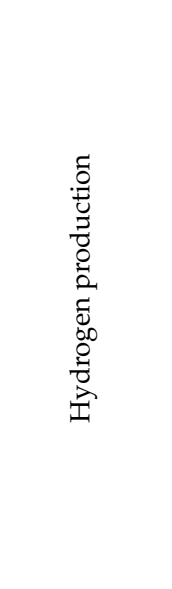 } & \multirow{4}{*}{$\begin{array}{l}\text { Blue hydrogen } \\
\text { production }\end{array}$} & Basic & 8926 & 5763 & 12,588 & 13,287 & 10,656 & 6250 & 57,468 & $-6.9 \%$ \\
\hline & & Applied & 1449 & 560 & 1125 & 995 & 477 & - & 4607 & $-24.2 \%$ \\
\hline & & Experimental & 6252 & 5019 & 7306 & 8288 & 6468 & 1550 & 34,883 & $-24.3 \%$ \\
\hline & & Others & 2261 & 7115 & 3167 & 2200 & - & - & 14,742 & $-0.9 \%$ \\
\hline & \multirow{4}{*}{$\begin{array}{l}\text { Green hydrogen } \\
\text { production }\end{array}$} & Basic & 10,284 & 14,870 & 12,339 & 11,249 & 6831 & 3469 & 59,042 & $-19.5 \%$ \\
\hline & & Applied & 1366 & 1383 & 3005 & 3365 & 12,175 & 10,789 & 32,083 & $51.2 \%$ \\
\hline & & Experimental & 4676 & 6776 & 7905 & 7486 & 10,090 & 2196 & 39,129 & $-14.0 \%$ \\
\hline & & Others & 4761 & 2767 & 1008 & 870 & - & 102 & 9508 & $-53.7 \%$ \\
\hline & \multirow{4}{*}{$\begin{array}{c}\text { Hydrogen } \\
\text { infrastructure and } \\
\text { safety }\end{array}$} & Basic & 3532 & 3125 & 5247 & 5271 & 3973 & 175 & 21,322 & $-45.2 \%$ \\
\hline & & Applied & 566 & 461 & 932 & 846 & 3561 & 4542 & 10,907 & $51.7 \%$ \\
\hline & & Experimental & 663 & 6765 & 4740 & 3920 & 5113 & 11,313 & 32,514 & $76.3 \%$ \\
\hline & & Others & - & 414 & 371 & 371 & 2440 & 513 & 4108 & $5.5 \%$ \\
\hline \multirow{8}{*}{ 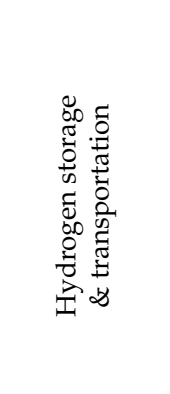 } & \multirow{4}{*}{$\begin{array}{l}\text { Hydrogen } \\
\text { transportation }\end{array}$} & Basic & - & - & - & - & - & - & - & - \\
\hline & & Applied & - & - & - & - & 2466 & 4921 & 7386 & $99.6 \%$ \\
\hline & & Experimental & - & 864 & 816 & 1467 & - & - & 3148 & $30.3 \%$ \\
\hline & & Others & - & - & - & - & 1171 & - & 1171 & \#DIV / 0 ! \\
\hline & \multirow{4}{*}{ Hydrogen storage } & Basic & 2870 & 1785 & 1549 & 1649 & 2194 & 2035 & 12,081 & $-6.6 \%$ \\
\hline & & Applied & 2305 & 1666 & 2077 & 2412 & 2506 & 6745 & 17,711 & $24.0 \%$ \\
\hline & & Experimental & 10,639 & 8965 & 6181 & 4309 & 7022 & 361 & 37,479 & $-49.2 \%$ \\
\hline & & Others & - & 183 & 628 & 754 & 1964 & - & 3529 & $120.8 \%$ \\
\hline \multirow{15}{*}{ 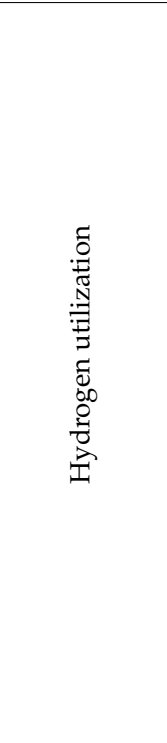 } & \multirow{3}{*}{ Power-to-X } & Basic & - & 406 & 572 & 542 & 497 & 542 & 2558 & $7.5 \%$ \\
\hline & & Applied & - & - & 323 & 264 & 290 & 792 & 1668 & $34.9 \%$ \\
\hline & & Experimental & - & - & - & - & 6856 & 8767 & 15,623 & $27.9 \%$ \\
\hline & \multirow{4}{*}{$\begin{array}{c}\text { Hydrogen } \\
\text { demonstration }\end{array}$} & Basic & 67 & 145 & 409 & 640 & 484 & 548 & 2293 & $52.2 \%$ \\
\hline & & Applied & - & - & - & 200 & 250 & 250 & 700 & $11.8 \%$ \\
\hline & & Experimental & 1115 & 1042 & 9892 & 3941 & - & 4657 & 20,646 & $33.1 \%$ \\
\hline & & Others & 3301 & 5435 & 25 & 25 & - & - & 8786 & $-80.4 \%$ \\
\hline & \multirow{4}{*}{$\begin{array}{l}\text { Hydrogen fueling } \\
\text { stations }\end{array}$} & Basic & - & - & 309 & 523 & 523 & 220 & 1574 & $-10.8 \%$ \\
\hline & & Applied & - & - & - & 287 & 2585 & 1141 & 4012 & $99.5 \%$ \\
\hline & & Experimental & 947 & 5821 & 5444 & 7558 & 8509 & 12,988 & 41,268 & $68.8 \%$ \\
\hline & & Others & - & - & 628 & 754 & 1473 & - & 2855 & $53.1 \%$ \\
\hline & \multirow{4}{*}{ Fuel cell } & Basic & 703 & 3712 & 4819 & 1301 & 910 & 1958 & 13,402 & $22.7 \%$ \\
\hline & & Applied & 1771 & 4708 & 3648 & 1208 & 1877 & 2685 & 15,897 & $8.7 \%$ \\
\hline & & Experimental & 3924 & 7038 & 3926 & 3312 & 2783 & 9446 & 30,429 & $19.2 \%$ \\
\hline & & Others & 204 & 483 & - & 48 & 420 & - & 1154 & $19.7 \%$ \\
\hline \multirow{4}{*}{\multicolumn{2}{|c|}{$\begin{array}{c}\text { Total } \\
\text { (Unit: USD million) }\end{array}$}} & Basic & 26,381 & 29,804 & 37,832 & 34,461 & 26,066 & 15,196 & 169,740 & $-10.4 \%$ \\
\hline & & Applied & 7456 & 8778 & 11,109 & 9578 & 26,186 & 31,864 & 94,972 & $33.7 \%$ \\
\hline & & Experimental & 28,217 & 42,290 & 46,209 & 40,282 & 46,840 & 51,279 & 255,118 & $12.7 \%$ \\
\hline & & Others & 10,526 & 16,396 & 5826 & 5022 & 7467 & 615 & 45,853 & $-43.3 \%$ \\
\hline
\end{tabular}

Additionally, the investment statuses of the nationally funded projects in 16 regions for hydrogen-economy-related technology clusters were investigated to identify the regional technological competitiveness. Interestingly, as presented in Table 8, the hydrogeneconomy-related R\&D capabilities were concentrated in Daejeon, in particular, a total of USD 175,515, which corresponds to $31 \%$ of the government's investment budget (Table 8 ). 
Out of it, USD 73,208 was utilized for blue hydrogen production, USD 55,799 was invested in green hydrogen production, and USD 23,309 was invested in hydrogen infrastructure and safety to intensively enhance competition in the value chain of the hydrogen production sector. Seoul, which ranked second regarding the total investment amount, focused on hydrogen storage, green hydrogen production, and FCs, while Jeollabuk-do, which ranked third, prioritized hydrogen storage, hydrogen infrastructure and safety, and hydrogen fueling stations. Further, Gyeonggi-do, Chungcheongnam-do, and Ulsan concentrated on FC and green hydrogen production, FCs, and hydrogen demonstration, respectively. Thus, each region exhibited a relative investment advantage only in a specific technology field. The overall investment status was considered insignificant if the investment is insufficient in other technology clusters, exhibiting the existence of regional concentration.

\subsubsection{Potential National Collaborative Research Organizations Based on the Technology Clusters}

Subsequently, the status of the investment was investigated based on the technology clusters, regions, and organization types to form a potential collaboration network between academia, industry, and research institutes in the technology segments of the national hydrogen economy (Table 9). The regional variations were caused by the differences in the development paths of the regions [26]. Thus, it was challenging for the regions to adopt different development pathways because of the limited relevant skills and assets in technology and organizations [13]. To effectively reduce such limitations for regions with less-favored research and innovation systems, it was necessary to grasp the R\&D projects that have been conducted therein and the responsible organizations in the specific research fields. This might be the regional basis for collaborating with the private companies in the regions to generate a green hydrogen value chain.

As emphasized by other scholars, the national hydrogen strategies can be accelerated by closely integrating the capabilities of the research organizations in the technological segments. Therefore, policymakers or directors of national R\&D programs must design transregional collaborative R\&D that considers the technological advancements of the research organizations in technological segments and regions. Regarding the companies in the low-innovation regions that are searching for universities and/or research institutes as potential partners, the government and/or committees must provide detailed information on the R\&D projects that such organizations have conducted, as well as the degree of the technology spectrum of the project in a specific field. Moreover, for the government and/or committees, this study presents information about eligible experts in academia, research institutes, and industry who might participate in ongoing discussions to make the best decision possible.

Here, we adopted the example of the green hydrogen production cluster to present useful information that was obtained from this study for an R\&D-spectrum-based strategic collaboration. Table 10 presents information on the representative research organizations, the project titles, the R\&D spectrum, and the funding from academia and research institutes for some regions in Korea. For example, with regard to the local government of Jeollabukdo with a plan to develop a specialized complex for green hydrogen production, the universities and research institutes in the region must be considered as the mission-alignedexpert group to promote the continuity of the research in the region and to share the knowledge regarding the technological applications. 
Table 8. Status of the hydrogen-economy-related research fields in 16 regions in Korea.

\begin{tabular}{|c|c|c|c|c|c|c|c|c|c|c|}
\hline \multirow[b]{2}{*}{ Region } & \multirow[b]{2}{*}{$\begin{array}{c}\text { Total } \\
\text { (Unit: } \\
\text { Thousand USD) }\end{array}$} & \multicolumn{3}{|c|}{ Hydrogen Production } & \multicolumn{2}{|c|}{ Hydrogen Storage and Transportation } & \multicolumn{4}{|c|}{ Hydrogen Utilization } \\
\hline & & $\begin{array}{c}\text { Blue } \\
\text { Hydrogen } \\
\text { Production }\end{array}$ & $\begin{array}{c}\text { Green } \\
\text { Hydrogen } \\
\text { Production }\end{array}$ & $\begin{array}{c}\text { Hydrogen } \\
\text { Infrastructure and } \\
\text { Safety }\end{array}$ & $\begin{array}{c}\text { Hydrogen } \\
\text { Transportation }\end{array}$ & Hydrogen Storage & Power-to-X & $\begin{array}{c}\text { Hydrogen } \\
\text { Demonstration }\end{array}$ & $\begin{array}{l}\text { Hydrogen } \\
\text { Fueling } \\
\text { Stations }\end{array}$ & Fuel Cell \\
\hline Gangwon-do & 1206 & & & & - & 1206 & - & - & & \\
\hline Gyeongsangnam-do & 22,896 & 1059 & 2358 & 7436 & - & 3790 & - & 2565 & 3552 & 2136 \\
\hline Gyeongsangbuk-do & 25,689 & 13,092 & 3672 & 625 & - & 3482 & - & 78 & - & 4740 \\
\hline Gwangju & 2873 & -0 & 1233 & 38 & - & 250 & - & - & - & 1352 \\
\hline Daegu & 1542 & - & 874 & 121 & - & 338 & - & - & - & 208 \\
\hline Daejeon & 175,515 & 73,208 & 55,799 & 23,309 & - & 10,980 & 1668 & 4486 & 404 & 5660 \\
\hline Busan & 28,652 & 85 & 10,036 & 4350 & 10,177 & 1173 & & 50 & 1974 & 807 \\
\hline Sejong & $\begin{array}{c}00,112 \\
273\end{array}$ & 1100 & $\begin{array}{c}19,050 \\
89\end{array}$ & 112 & - & 20,001 & 2000 & 412 & 1029 & $\begin{array}{c}10,117 \\
73\end{array}$ \\
\hline Ulsan & 37,986 & 170 & 15,226 & 300 & - & 1257 & - & 20,227 & - & 807 \\
\hline Incheon & 10,693 & 7019 & 131 & 377 & - & 1167 & - & $20,-$ & - & 2000 \\
\hline Jeollanam-do & 2600 & 1717 & 644 & & - & $110 \%$ & - & 90 & - & 150 \\
\hline Jeollabuk-do & 62,468 & 117 & 424 & 2628 & - & 18,008 & 15,623 & 4518 & 16,157 & 5109 \\
\hline Chungcheongnam-do & 54,530 & 1343 & 8940 & 17,505 & 1529 & 391 & - & - & 15,654 & 9169 \\
\hline Chungcheongbuk-do & 11,748 & 9968 & 39 & - & - & 890 & - & - & & $\begin{array}{l}9169 \\
890\end{array}$ \\
\hline Total & 565,683 & 111,701 & 139,762 & 68,851 & 11,705 & 70,800 & 19,849 & 32,425 & 49,710 & 60,881 \\
\hline
\end{tabular}


Table 9. Status of the investment based on the clusters, regions, and organization types.

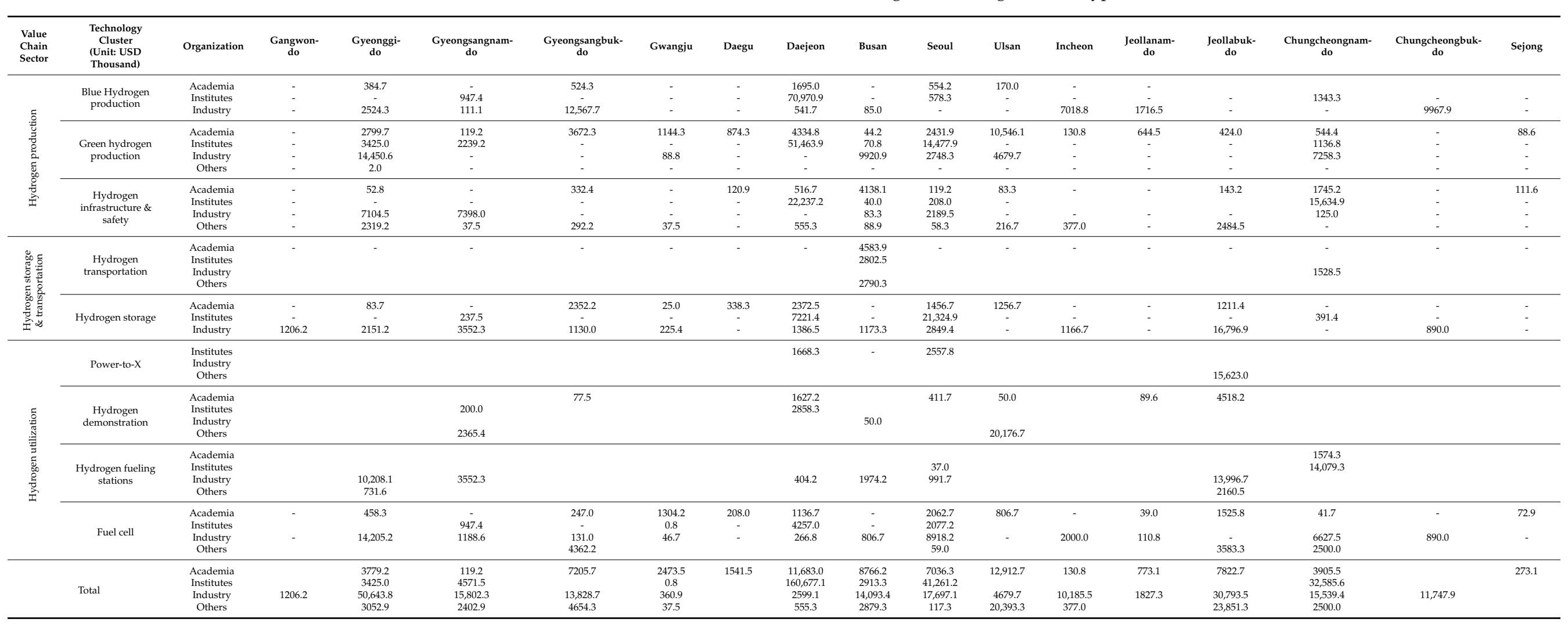


Table 10. Representative research organizations, project titles, and funding from academia, research institutes, industry, and other organizations for the 17 regions in Korea.

\begin{tabular}{|c|c|c|c|c|c|c|}
\hline Region & $\begin{array}{c}\text { Type of } \\
\text { Organization }\end{array}$ & Organization & R\&D Title & R\&D Spectrum & Project Manager & $\begin{array}{c}\text { Funding } \\
\text { (Thousand USD }\end{array}$ \\
\hline \multirow{2}{*}{ Gyeonggi-do } & Academia & Sungkyunkwan University & $\begin{array}{l}\text { Development of lignin-to-transportation fuel using } \\
\text { self-generated active hydrogen-based thermochemical pro }\end{array}$ & Basic & Jaehoon Kim & 746.8 \\
\hline & Institutes & $\begin{array}{l}\text { Institute for Advanced } \\
\text { Engineering }\end{array}$ & $\begin{array}{l}\text { Bio-hydrogen mass production process development and } \\
\text { process design }\end{array}$ & Experimental & Youngdon Yoo & 1241.7 \\
\hline \multirow{2}{*}{ Gyeongsangnam-do } & Academia & Gyeongsang National University & $\begin{array}{l}\text { Development of High-Performance Random/Graft copolymer } \\
\text { Polymer Electrolyte Membranes with Nanophase-separated } \\
\text { Structure }\end{array}$ & Experimental & Sangyong Nam & 119.2 \\
\hline & Institutes & $\begin{array}{l}\text { Korea Institute of Materials } \\
\text { Science }\end{array}$ & $\begin{array}{c}\text { Development of manufacturing process for OER electrode of } \\
\text { PEM water electrolyzer }\end{array}$ & Basic & Seunghoe Choi & 208.3 \\
\hline \multirow[b]{2}{*}{ Gyeongsangbuk-do } & Academia & $\begin{array}{l}\text { Pohang University of Science and } \\
\text { Technology }\end{array}$ & $\begin{array}{l}\text { Water Treatment and Pollutants Control with Simultaneous } \\
\text { Recovery of Energy Using Semiconductor-based Hybrid } \\
\text { Functional Materials }\end{array}$ & Basic & Wonyong Choi & 2180.0 \\
\hline & Academia & Yeungnam University & $\begin{array}{c}\text { Development of low concentrated and high dispersed noble } \\
\text { metal core/shell structured materials for application to } \\
\text { high-hydrogen production from oxidized hydrocarbon } \\
\text { reforming reaction }\end{array}$ & Basic & Misook Kang & 125.8 \\
\hline \multirow{2}{*}{ Gwangju } & Academia & $\begin{array}{l}\text { Gwangju Institute of Science and } \\
\text { Technology (GIST) }\end{array}$ & $\begin{array}{c}\text { Numerical simulation of vibrational spectrum in aqueous } \\
\text { solution }\end{array}$ & Basic & Junho Choi & 114.6 \\
\hline & Academia & $\begin{array}{l}\text { Gwangju Institute of Science and } \\
\text { Technology (GIST) }\end{array}$ & $\begin{array}{l}\text { Digital twin technology development for the optimal control } \\
\text { strategy establishment of the alkaline water electrolyzer system }\end{array}$ & Applied & Sanggyu Kang & 411.7 \\
\hline \multirow[t]{2}{*}{ Daegu } & Academia & $\begin{array}{l}\text { Daegu Gyeongbuk Institute of } \\
\text { Science and Technology (DGIST) }\end{array}$ & $\begin{array}{l}\text { Development of High-Efficiency Low Temperature }\left(\leq 550^{\circ} \mathrm{C}\right) \\
\text { Solid Oxide Electrolysis Cell (LT-SOEC) based on Super Ion } \\
\text { Conductor for High Purity Carbon-Free Hydrogen Production }\end{array}$ & Experimental & Kang-taek Lee & 150.0 \\
\hline & Academia & $\begin{array}{l}\text { Daegu Gyeongbuk Institute of } \\
\text { Science and Technology (DGIST) }\end{array}$ & Novel organic/inorganic molecular energy hybrid technology & Basic & Jong-seong Yoo & 641.0 \\
\hline \multirow{4}{*}{ Daejeon } & Academia & $\begin{array}{l}\text { Korea Advanced Institute of } \\
\text { Science and Technology (KAIST) }\end{array}$ & $\begin{array}{l}\text { Development of High-Efficiency Low Temperature }\left(\leq 550^{\circ} \mathrm{C}\right) \\
\text { Solid Oxide Electrolysis Cell (LT-SOEC) based on Super Ion } \\
\text { Conductor for High Purity Carbon-Free Hydrogen Production }\end{array}$ & Experimental & Kang-taek Lee & 208.3 \\
\hline & Institutes & Korea Institute of Energy Research & Reversible high-temperature cells using multi-scale solid oxide & Experimental & Sang-guk Woo & 1583.3 \\
\hline & Institutes & Korea Institute of Energy Research & Development of Next Generation Alkaline Electrolyzer & Applied & Chang-hee Kim & 4100.0 \\
\hline & Institutes & $\begin{array}{l}\text { Korea Research Institute of } \\
\text { Chemical Technology }\end{array}$ & $\begin{array}{l}\text { Development of electrolyte membranes based on } \\
\text { nonperfluorinated random/block copolymer membranes }\end{array}$ & Applied & Young-taek Hong & 805.0 \\
\hline
\end{tabular}


Table 10. Cont.

\begin{tabular}{|c|c|c|c|c|c|c|}
\hline Region & $\begin{array}{c}\text { Type of } \\
\text { Organization }\end{array}$ & Organization & R\&D Title & R\&D Spectrum & Project Manager & $\begin{array}{c}\text { Funding } \\
\text { (Thousand USD) }\end{array}$ \\
\hline \multirow{4}{*}{ Seoul } & Academia & Seoul National University & $\begin{array}{l}\text { Transition metal-based flexible electrode for hydrogen } \\
\text { production using super-saturated alloy }\end{array}$ & Experimental & KItae Nam & 630.7 \\
\hline & Academia & Korea University & $\begin{array}{l}\text { Development of highly active reduced precious metal, novel } \\
\text { electro-catalysts for treatment of wastewater }\end{array}$ & Experimental & Dongwan Kim & 1074.2 \\
\hline & Institutes & $\begin{array}{l}\text { Korea Institute of Science and } \\
\text { Technology (KIST) }\end{array}$ & $\begin{array}{l}\text { Development of electrochemical membrane reactor for } \\
\text { hydrogen \& syn gas fabrication }\end{array}$ & Experimental & Seongpil Yoon & 1172.9 \\
\hline & Institutes & $\begin{array}{l}\text { Korea Institute of Science and } \\
\text { Technology (KIST) }\end{array}$ & $\begin{array}{l}\text { Development of membrane electrode assembly and stack for } \\
\text { polymer electrolyte membrane (PEM) water electrolyzer }\end{array}$ & Applied & Jonghyun Jang & 1941.7 \\
\hline \multirow{2}{*}{ Ulsan } & Academia & $\begin{array}{l}\text { Ulsan National Institute of Science } \\
\text { and Technology (UNIST) }\end{array}$ & $\begin{array}{l}\text { Renewable Hydrogen Production by High-Efficiency Solar } \\
\text { Energy Harvesting and Conversion }\end{array}$ & Basic & Jae-Sung Lee & 1341.3 \\
\hline & Academia & $\begin{array}{l}\text { Ulsan National Institute of Science } \\
\text { and Technology (UNIST) }\end{array}$ & $\begin{array}{l}\text { Integrative techno-economic and prognostic analysis for } \\
\text { alkaline water electrolyzer stack }\end{array}$ & Applied & Ha-kwon Im & 327.5 \\
\hline Incheon & Academia & Inha University & $\begin{array}{c}\text { Development of alkaline water electrolyzer model and } \\
\text { design technology }\end{array}$ & Basic & Hyun-cheol Joo & 130.8 \\
\hline \multirow[t]{2}{*}{ Jeollabuk-do } & Academia & JeonBuk National University & $\begin{array}{l}\text { Development of } \mathrm{Mg} / \text { carbon nanocomposites with high } \\
\text { hydrogen-storage capacity and hydriding and dehydriding } \\
\text { rates by adding carbonaceous materials, transition metals, } \\
\text { and compounds }\end{array}$ & Basic & Myung-yeop Song & 124.3 \\
\hline & Academia & JeonBuk National University & $\begin{array}{c}\text { Development of Highly Efficient Heterojunction typed } \\
\text { Photoanode Materials and PEC System for Solar Hydrogen } \\
\text { Production based on Nanostructure }\end{array}$ & Basic & Jum Suk Jang & 166.7 \\
\hline \multirow{3}{*}{$\begin{array}{l}\text { Chungcheongnam- } \\
\text { do }\end{array}$} & Academia & Dankook University & $\begin{array}{l}\text { The development of perfluorinated anion-conducting ionomers } \\
\text { and their membranes with high ion conductivity, excellent } \\
\text { chemical resistance, and scale-up capability }\end{array}$ & Applied & Changhyun Lee & 409.2 \\
\hline & Institutes & $\begin{array}{l}\text { Korea Institute of Industrial } \\
\text { Technology }\end{array}$ & $\begin{array}{l}\text { Development of large-scale electrode manufacturing } \\
\text { technology for electrolysis via electrodeposition and } \\
\text { electrophoresis synthesis }\end{array}$ & Applied & Min-young Lee & 461.8 \\
\hline & Institutes & $\begin{array}{l}\text { Korea Institute of Industrial } \\
\text { Technology }\end{array}$ & $\begin{array}{l}\text { Source Technology Development for Simultaneous Production } \\
\text { of Biopolymer and Bio-hydrogen Using Seaweed Biomass }\end{array}$ & Basic & Jeong-Jun Yoon & 633.3 \\
\hline
\end{tabular}




\section{Discussion}

\subsection{RED Investment and Collaboration Framework for the National Hydrogen Strategy}

The proposed investment and collaboration framework for the national hydrogen strategy presents a variety of information to elucidate in detail the technology segments, R\&D spectrum, and regional dimensions. To demonstrate the application of the framework, three research questions (RQ) (three sub-research questions in RQ1, RQ2, and RQ3) were raised. First, on the basis of RQ1-1 and RQ1-2, the overall status and R\&D spectrum of government investment in the value chain of the hydrogen economy between 2015 and 2020 were revealed. Additionally, on the basis of RQ1-3, the overall status of the regional government investments was illustrated to bridge the gap in regional investments. This information may be a good precursor for many stakeholders to evaluate the spectrum of hydrogen-economy-related technology and discuss the directions of national $R \& D$ investment, to improve the regions with regard to reliable sources and objective analyses. Secondly, on the basis of RQ2-1 and RQ2-2, the trends of the investment in hydrogen-economy-related technologies, and their spectrum between 2015 and 2020, were presented. The statuses of the hydrogen-economy-related research fields in 16 regions were also demonstrated based on RQ2-3. This information elucidated the mid-term trend of public investment regarding the value chain of the hydrogen economy and the R\&D spectrum, thus generating a variety of topics on the scale and portfolio of the investment. Thirdly, on the basis of RQ3-1, we presented information to elucidate the comprehensive competitiveness of the hydrogen-economy-related fields from the viewpoints of research organizations. Finally, on the basis of RQ3-2, we indicated the qualified local research organizations, their R\&D activities, and the R\&D spectra of their projects based on the nine hydrogen-economy-related technology areas, including academia, industry, and research institutes. For many stakeholders, as well as investment- and R\&D-spectrum-based research partners, the information on the nine classified hydrogen-economy-related fields and 16 regions in this study can be adopted as a basis for activating the mechanisms to enhance improved strategic research collaboration.

Sustained public investment is a key factor to increasing the demand and improving the productivities of national strategic industries in the nascent stage, thereby contributing to their economic growth. Particularly, leading countries have developed their hydrogen strategies to achieve carbon neutrality and regional equality with the impetus of the COVID-19 pandemic [2,9]. On the basis of the results of the analyses of public investment in the R\&D of the hydrogen economy, the bulk of public investment in Korea is focused on hydrogen (electric) vehicles and their related technologies and infrastructures, such as FCs and fueling stations (utilization), rather than on production. On the basis of the review of the National Hydrogen Roadmap (Section 1.1.1), the technical and cost targets for producing hydrogen can be achieved by investing in crucial blue and/or green hydrogen-production-related technologies [16]. However, the results indicate that the investment strategy of the government is focused on hydrogen cell (electric) vehicles and FCs (hydrogen utilization) rather than on hydrogen production. Therefore, a decrease in the national competitiveness of the crucial technology fields in the value chain of the hydrogen economy is surely anticipated. The committees may raise topics of discussion about the directions of the national R\&D strategy employing the nationally funded projects-based analytical information. This study can improve the limitations of previous studies $[2,4,9,10,18,19,27,29,30,32-36]$ in the following ways: the normative statement that governments should endeavor to accelerate the transition into the hydrogen economy can be empowered by the information about the public investment trends of the government, which elucidates the role of government commitment to continuous investment. The other is that the quantitative analyses, based on publications or patents alone, cannot elucidate the scale of funding and technological advancement of hydrogen-economy-related research projects. This limitation can be overcome by presenting detailed information about the funding scale, technological advancement, purpose, and organizations responsible for projects in the technology segment of the value chain of the hydrogen economy. This 
might strengthen strategic research collaboration by aligning different technical objectives. Technologies in the applied research and experimental development stages of the R\&D spectra that were conducted by academia and/or research institutes are required to connect with the private sectors to include commercial feasibility studies and corroborate whether an industrial requirement was met or not. With regard to national R\&D program managers, this information can facilitate the design of an academia-research institutes-industry research collaboration structure during the program planning process.

\subsection{Conclusions}

The Korean government recently engaged in a series of activities to achieve a netzero carbon society. This series began with the announcement of the Hydrogen Economy Roadmap in January 2019, the establishment of the Hydrogen Act in February 2020 (enforced on 5 February 2021), and the Green New Deal in July 2020. Thus, a long-term commitment to public support and funding toward green R\&D is required to accomplish the transition to the hydrogen economy $[7,15]$, as supported by the need for an R\&D investment and collaboration framework, which considers the trends of the investment and R\&D spectra of the hydrogen-economy-related technology segments of the value chain of the hydrogen economy, to promote the government's commitment. Moreover, as emphasized in our previous study [54], the framework would also present the information on the regional variations that are caused by differences in the endowment of relevant assets, although it is challenging to reduce the regional inequality via a transregional research collaboration approach. In our last study [54], we proposed the transregional collaboration framework and demonstrated it with a sample of future mobility. However, it is necessary to elaborate the previously proposed framework to present more valuable information about the R\&D-spectrum-based research collaboration among academia, research institutes, and industries in Korea, thus establishing a systematic approach for creating a new green value chain for the hydrogen economy by combining the existing innovative capabilities of various research organizations.

Therefore, this study offers two valuable contributions. First, we present an advanced framework that presents information about the statuses and trends of public investment in the technology segments of a target domain from the dual viewpoints of the regions and the R\&D spectra. On the basis of our previous study [54], the data of nationally funded research projects, which contain the aim and contents of the projects, the project periods, the funding, and the R\&D spectra, were adopted. Thus, this information allows R\&D managers to design a strategic collaboration employing limited resources, a lack of knowledge, and uncertainty about the market in the nascent hydrogen industry.

The second major contribution of this study is that it demonstrates how to operate the framework employing the hydrogen economy case. Hydrogen production accounted for the largest proportion of the total scale of government funding between 2015 and 2020, rather than hydrogen storage, transportation, and utilization. However, the investment trend of funding within the last five years raised concerns regarding the decrease in public funding for core technologies, such as the productions of blue and green hydrogen, thus inevitably obstructing the transition into the hydrogen economy. Interestingly, research organizations in Daejeon acquired the maximum government R\&D funding for most hydrogen-economy-related technology fields between 2015 and 2020. The regional concentration of hydrogen-related technology investment raised concerns over the diminishing returns to R\&D, which was caused by the constraints to both the internal and external sources of new knowledge for innovative development. Adversely, some local governments pursuing specialized hydrogen complexes, such as the green hydrogen production by Jeollabuk-do, confront limited resources to invest continuously for the accumulated absorptive capacity of the region, which is the key driver of both economic growth and sustainable competitive advantage. 


\subsection{Limitations and Further Research}

Despite these contributions, this study also posed the same limitations that presented challenging questions for future research in the previous study [54]. One concern is that only the data of nationally funded research projects from the central government were utilized so that the R\&D expenditures of the 17 local governments were required to be integrated into the proposed framework to accurately understand the current status and trends of the hydrogen-economy-related technologies. Another limitation that can be corrected by future studies is the lack of funding data from developed countries, such as the US and EU, in the global hydrogen economy, which could be employed to conduct a comparative analysis to establish an international strategy research collaboration network among the technology segments working toward a hydrogen economy.

Author Contributions: Conceptualization, D.L.; data curation, D.L.; formal analysis, D.L.; funding acquisition, K.K.; investigation, D.L.; methodology, K.K.; project administration, K.K.; resources, D.L.; software, K.K.; supervision, K.K.; validation, K.K.; visualization, D.L. and K.K.; writing-original draft, D.L. and K.K.; writing-review and editing, K.K. Both authors have read and agreed to the published version of the manuscript.

Funding: This research was supported by the Korea Institute of Science and Technology Information (KISTI) of the Ministry of Science and ICT, Korea (MSIT) (No. K-21-L03-C04-S01: Advancement of innovation strategy analysis models for science, technology, and industry and No. K-20-L03-C03-S01: Artificial intelligence-based decision making for supporting national R\&D policy).

Institutional Review Board Statement: Not applicable.

Informed Consent Statement: Not applicable.

Data Availability Statement: Not applicable.

Conflicts of Interest: The authors declare no conflict of interest.

\section{References}

1. Khalilpour, K.R.; Pace, R.; Karimi, F. Retrospective and Prospective of the Hydrogen Supply Chain: A Longitudinal TechnoHistorical Analysis. Int. J. Hydrogen Energy 2020, 45, 34294-34315. [CrossRef]

2. Kasai, H.; Padama, A.A.B.; Chantaramolee, B.; Arevalo, R.L. Hydrogen and Hydrogen-Containing Molecules on Metal Surfaces; Springer Series in Surface Sciences; Springer: Singapore, 2020; Volume 71. [CrossRef]

3. Nuttall, W.J.; Bakenne, A.T. Fossil Fuel Hydrogen; Springer Nature: Basingstoke, UK, 2020. [CrossRef]

4. Mohideen, M.M.; Ramakrishna, S.; Prabu, S.; Liu, Y. Advancing Green Energy Solution with the Impetus of COVID-19 Pandemic. J. Energy Chem. 2021, 59, 688-705. [CrossRef]

5. Delbeke, J.; Vis, P. Towards a Climate-Neutral Europe; Delbeke, J., Vis, P., Eds.; Routledge: London, UK, 2019. [CrossRef]

6. Galvin, R.; Healy, N. The Green New Deal in the United States: What It Is and How to Pay for It. Energy Res. Soc. Sci. 2020, 67, 101529. [CrossRef]

7. Cheon, K.; Kim, J. Hydrogen Economy in Major Countries: Policies of Promotion and Lessons Learnt from Them. J. Korean Soc. Miner. Energy Resour. Eng. 2020, 57, 629-639. [CrossRef]

8. Government of the Republic of Korea. Korean New Deal. 2020. Available online: https://english.moef.go.kr/pc/selectTbPressC enterDtl.do?boardCd=N0001\&seq $=4948$ (accessed on 2 August 2021).

9. Stangarone, T. South Korean Efforts to Transition to a Hydrogen Economy. Clean Technol. Environ. Policy 2021, $23,509-516$. [CrossRef]

10. Dou, Y.; Sun, L.; Ren, J.; Dong, L. Opportunities and Future Challenges in Hydrogen Economy for Sustainable Development; Elsevier Ltd.: Amsterdam, The Netherlands, 2017. [CrossRef]

11. European Commission. A Hydrogen Strategy for a Climate-Neutral Europe. 2020. Available online: https://ec.europa.eu/energ y/sites/ener/files/hydrogen_strategy.pdf (accessed on 20 July 2021).

12. FCHEA. Road Map to a US Hydrogen Economy. 2020. Available online: https://static1.squarespace.com/static/53ab1feee4b0bef 0179a1563/t/5e7ca9d6c8fb3629d399fe0c/1585228263363/Road+Map+to+a+US+Hydrogen+Economy+Full+Report.pdf (accessed on 15 July 2021).

13. Chaube, A.; Chapman, A.; Shigetomi, Y.; Huff, K.; Stubbins, J. The Role of Hydrogen in Achieving Long Term Japanese Energy System Goals. Energies 2020, 13, 4539. [CrossRef]

14. Intralink. The Hydrogen Economy South Korea. 2011. Available online: https://www.intralinkgroup.com/Syndication/media /Syndication/Reports/Korean-hydrogen-economy-market-intelligence-report-January-2021.pdf (accessed on 17 July 2021). 
15. The Ministry of Trade Industry and Energy. Hydrogen Economy Roadmap. 2019. Available online: https://www.motie.go.kr/co mmon/download.do?fid=bbs\&bbs_cd_n=81\&bbs_seq_n=161262\&file_seq_n=2 (accessed on 3 July 2021).

16. The Ministry of Trade Industry and Energy. Hydrogen Economy Fostering and Hydrogen Safety Management Act. 2021. Available online: https: / www.law.go.kr/\%EB\%B2\%95\%EB\%A0\%B9/\%EC\%88\%98\%EC\%86\%8C\%EA\%B2\%BD\%EC\%A0\%9

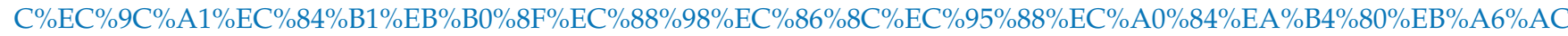
\%EC $\% 97 \% 90 \%$ EA $\%$ B4\%80\%ED \%95\%9C\%EB\%B2\%95\%EB\%A5\%A0/(16942,20200204) (accessed on 15 July 2021).

17. IRENA. Innovation Landscape Brief: Renewable Power-to-Hydrogen, International Renewable Energy. 2019. Available online: https:/ / www.irena.org/-/media/Files/IRENA/Agency/Publication/2019/Sep/IRENA_Power-to-Hydrogen_Innovati on_2019.pdf (accessed on 17 July 2021).

18. Li, Z.; Zhang, W.; Zhang, R.; Sun, H. Development of Renewable Energy Multi-Energy Complementary Hydrogen Energy System (A Case Study in China): A Review. Energy Explor. Exploit. 2020, 38, 2099-2127. [CrossRef]

19. Popov, S.; Maksakova, D.; Baldynov, O.; Korneev, K. Hydrogen Energy: A New Dimension for the Energy Cooperation in the Northeast Asian Region. In E3S Web of Conferences; EDP Sciences: Les Ulis, France, 2020; Volume 209, p. 05017. [CrossRef]

20. Scherer, F.L.; Minello, I.F.; Krüger, C.; Rizzatti, A.B. To Internationalize or Not to Internationalize? A Descriptive Study of a Brazilian Startup. Technol. Innov. Manag. Rev. 2018, 8, 38-46. [CrossRef]

21. Bloomfield, J.; Steward, F. The Politics of the Green New Deal. Polit. Q. 2020, 91, 770-779. [CrossRef]

22. Barbier, E.B. Greening the Post-Pandemic Recovery in the G20. Environ. Resour. Econ. 2020, 76, 685-703. [CrossRef]

23. Lee, J.-H.; Woo, J. Green New Deal Policy of South Korea: Policy Innovation for a Sustainability Transition. Sustainability 2020, 12, 10191. [CrossRef]

24. The Ministry of Trade Industry and Energy. Plan to Strengthen the Competitiveness of the Hydrogen Industry Ecosystem. 2020. Available online: http:/ / www.motie.go.kr/common/download.do?fid=bbs\&bbs_cd_n=81\&bbs_seq_n=163095\&file_seq_n=1 (accessed on 17 July 2021).

25. Sul-Ki, L.; Yeonhong, Y. The Grand Transition toward a Low-Carbon Economy Date. 2020. Available online: https://www.invest korea.org/ik-en/bbs/i-308/detail.do?ntt_sn=490755 (accessed on 25 July 2021).

26. Staffell, I.; Scamman, D.; Velazquez Abad, A.; Balcombe, P.; Dodds, P.E.; Ekins, P.; Shah, N.; Ward, K.R. The Role of Hydrogen and Fuel Cells in the Global Energy System. Energy Environ. Sci. 2019, 12, 463-491. [CrossRef]

27. Scita, R.; Raimondi, P.P.; Noussan, M. Green Hydrogen: The Holy Grail of Decarbonisation? An Analysis of the Technical and Geopolitical Implications of the Future Hydrogen Economy; Fondazione Eni Enrico Mattei: Milano, Italy, 2020.

28. DOE. Hydrogen Program Plan. 2020. Available online: https://www.hydrogen.energy.gov/pdfs/hydrogen-program-plan-2020. pdf (accessed on 19 July 2021).

29. Falcone, P.M.; Hiete, M.; Sapio, A. Hydrogen Economy and Sustainable Development Goals: Review and Policy Insights. Curr. Opin. Green Sustain. Chem. 2021, 31, 100506. [CrossRef]

30. De Backer, K.; Miroudot, S. Mapping Global Value Chains 2014. OECD Trade Policy Pap. 2013, 159, 1-46. [CrossRef]

31. Morciano, C.; Errico, M.C.; Faralli, C.; Minghetti, L. An Analysis of the Strategic Plan Development Processes of Major Public Organisations Funding Health Research in Nine High-Income Countries Worldwide. Health Res. Policy Syst. 2020, 18, 106. [CrossRef] [PubMed]

32. Tsay, M.Y. A Bibliometric Analysis of Hydrogen Energy Literature, 1965-2005. Scientometrics 2008, 75, 421-438. [CrossRef]

33. Maghami, M.R.; Asl, S.N.; esmaeil Rezadad, M.; Ale Ebrahim, N.; Gomes, C. Qualitative and Quantitative Analysis of Solar Hydrogen Generation Literature from 2001 to 2014. Scientometrics 2015, 105, 759-771. [CrossRef]

34. Chanchetti, L.F.; Leiva, D.R.; Lopes de Faria, L.I.; Ishikawa, T.T. A Scientometric Review of Research in Hydrogen Storage Materials. Int. J. Hydrogen Energy 2020, 45, 5356-5366. [CrossRef]

35. Md Khudzari, J.; Kurian, J.; Tartakovsky, B.; Raghavan, G.S.V. Bibliometric Analysis of Global Research Trends on Microbial Fuel Cells Using Scopus Database. Biochem. Eng. J. 2018, 136, 51-60. [CrossRef]

36. Mikheev, A.V. Technological Forecasting Related to the Energy Sector: A Scientometric Overview. In E3S Web of Conferences; EDP Sciences: Les Ulis, France, 2020; Volume 209, p. 02022. [CrossRef]

37. Xu, L.; Wang, Y.; Shah, S.A.; Zameer, H.; Solangi, Y.A.; Walasai, G.D.; Siyal, Z.A. Economic Viability and Environmental Efficiency Analysis of Hydrogen Production Processes for the Decarbonization of Energy Systems. Processes 2019, 7, 494. [CrossRef]

38. Xu, L.; Shah, S.A.A.; Zameer, H.; Solangi, Y.A. Evaluating Renewable Energy Sources for Implementing the Hydrogen Economy in Pakistan: A Two-Stage Fuzzy MCDM Approach. Environ. Sci. Pollut. Res. 2019, 26, 33202-33215. [CrossRef]

39. Shah, S.A.A. Feasibility Study of Renewable Energy Sources for Developing the Hydrogen Economy in Pakistan. Int. J. Hydrogen Energy 2020, 45, 15841-15854. [CrossRef]

40. Ogawa, T.; Takeuchi, M.; Kajikawa, Y. Analysis of Trends and Emerging Technologies in Water Electrolysis Research Based on a Computational Method: A Comparison with Fuel Cell Research. Sustainability 2018, 10, 478. [CrossRef]

41. Jiang, S.; Hagesteijn, K.F.L.; Ni, J.; Ladewig, B.P. A Scientometric Study of the Research on Ion Exchange Membranes. RSC Adv. 2018, 8, 24036-24048. [CrossRef]

42. Liu, W.; Sun, L.; Li, Z.; Fujii, M.; Geng, Y.; Dong, L.; Fujita, T. Trends and Future Challenges in Hydrogen Production and Storage Research. Environ. Sci. Pollut. Res. 2020, 27, 31092-31104. [CrossRef]

43. Yonoff, R.E.; Ochoa, G.V.; Cardenas-Escorcia, Y.; Silva-Ortega, J.I.; Meriño-Stand, L. Research Trends in Proton Exchange Membrane Fuel Cells during 2008-2018: A Bibliometric Analysis. Heliyon 2019, 5, e01724. [CrossRef] 
44. Bello, I.T.; Zhai, S.; He, Q.; Xu, Q.; Ni, M. Scientometric Review of Advancements in the Development of High-Performance Cathode for Low and Intermediate Temperature Solid Oxide Fuel Cells: Three Decades in Retrospect. Int. J. Hydrogen Energy 2021, 46, 26518-26536. [CrossRef]

45. Pamplona Solis, B.; Cruz Argüello, J.C.; Gómez Barba, L.; Gurrola, M.P.; Zarhri, Z.; TrejoArroyo, D.L. Bibliometric Analysis of the Mass Transport in a Gas Diffusion Layer in PEM Fuel Cells. Sustainability 2019, 11, 6682. [CrossRef]

46. Alvarez-Meaza, I.; Zarrabeitia-Bilbao, E.; Rio-Belver, R.M.; Garechana-Anacabe, G. Fuel-Cell Electric Vehicles: Plotting a Scientific and Technological Knowledge Map. Sustainability 2020, 12, 2334. [CrossRef]

47. Shi, X.; Cai, L.; Song, H. Discovering Potential Technology Opportunities for Fuel Cell Vehicle Firms: A Multi-Level Patent Portfolio-Based Approach. Sustainability 2019, 11, 6381. [CrossRef]

48. Inzelt, A. The Evolution of University-Industry-Government Relationships during Transition. Res. Policy 2004, 33, 975-995. [CrossRef]

49. Heo, Y.; Kang, J.; Kim, K. National Scientific Funding for Interdisciplinary Research: A Comparison Study of Infectious Diseases in the US and EU. Sustainability 2019, 11, 4120. [CrossRef]

50. OECD. G20 Innovation Report 2016. 2016. Available online: https://www.oecd.org/china/G20-innovation-report-2016.pdf (accessed on 16 July 2021).

51. Lee, D.; Kang, J.; Kim, K. Global Collaboration Research Strategies for Sustainability in the Post COVID-19 Era: Analyzing Virology-Related National-Funded Projects. Sustainability 2020, 12, 6561. [CrossRef]

52. Lee, D.; Kim, S.; Kim, K. International R\&d Collaboration for a Global Aging Society: Focusing on Aging-Related National-Funded Projects. Int. J. Environ. Res. Public Health 2020, 17, 8545. [CrossRef]

53. Al Nahyan, M.T.; Sohal, A.; Hawas, Y.; Fildes, B. Communication, Coordination, Decision-Making, and Knowledge-Sharing: A Case Study in Construction Management. J. Knowl. Manag. 2019, 23, 1764-1781. [CrossRef]

54. Lee, D.; Kim, K. A Collaborative Trans-Regional R\&D Strategy for the South Korea Green New Deal to Achieve Future Mobility. Sustainability 2021, 13, 8637. [CrossRef]

55. Lee, D.; Heo, Y.; Kim, K. A Strategy for International Cooperation in the Covid-19 Pandemic Era: Focusing on National Scientific Funding Data. Healthcare 2020, 8, 204. [CrossRef] 